Article

\title{
Hydrogen Evolution Reaction Property of Molybdenum Disulfide/Nickel Phosphide Hybrids in Alkaline Solution
}

\author{
Fan Yang, Ning Kang, Jiayun Yan, Xiuli Wang, Jun He, Siyue Huo and Laizhou Song * (iD \\ College of Environmental and Chemical Engineering, Yanshan University, Qinhuangdao 066004, China; \\ m15903396256@163.com (F.Y.); m18332559448@163.com (N.K.); yanjiayun0327@163.com (J.Y.); \\ xlwang790412@163.com (X.W.); hejun@ysu.edu.cn (J.H.); s15930599589@163.com (S.H.) \\ * Correspondence: songlz@ysu.edu.cn; Tel.: +86-335-838-7741; Fax: +86-335-806-1569
}

Received: 9 March 2018; Accepted: 14 May 2018; Published: 16 May 2018

\begin{abstract}
The hydrogen evolution reaction (HER) property of molybdenum disulfide $\left(\mathrm{MoS}_{2}\right)$ is undesirable because of the insufficient active edge sites and the poor conductivity. To enhance HER performance of $\mathrm{MoS}_{2}$, nickel phosphide $\left(\mathrm{Ni}_{2} \mathrm{P}\right)$ was combined with this catalyst and three $\mathrm{MoS}_{2} / \mathrm{Ni}_{2} \mathrm{P}$ hybrids (38 wt $\% \mathrm{Ni}_{2} \mathrm{P}$ addition for $\mathrm{MoS}_{2} / \mathrm{Ni}_{2} \mathrm{P}-38,50$ wt $\% \mathrm{Ni}_{2} \mathrm{P}$ addition for $\mathrm{MoS}_{2} / \mathrm{Ni}_{2} \mathrm{P}-50$, and $58 \mathrm{wt} \% \mathrm{Ni}_{2} \mathrm{P}$ addition for $\left.\mathrm{MoS}_{2} / \mathrm{Ni}_{2} \mathrm{P}-58\right)$ were fabricated via a hydrothermal synthesis process. Morphologies, crystallinities, chemical components, specific surface areas, and HER properties of the fabricated $\mathrm{MoS}_{2} / \mathrm{Ni}_{2} \mathrm{P}$ samples in an alkaline electrolyte were characterized and tested. In addition, the insight into the HER properties of as-prepared catalysts were revealed by the density functional theory (DFT) calculation. Additionally, the stabilities of pure $\mathrm{MoS}_{2}, \mathrm{Ni}_{2} \mathrm{P}$, and $\mathrm{MoS}_{2} / \mathrm{Ni}_{2} \mathrm{P}-50$ samples were evaluated. The results show that the addition of $\mathrm{Ni}_{2} \mathrm{P}$ can enhance the HER property of the $\mathrm{MoS}_{2}$ catalyst. Although HER properties of the above-mentioned three $\mathrm{MoS}_{2} / \mathrm{Ni}_{2} \mathrm{P}$ hybrids are inferior to that of pure $\mathrm{Ni}_{2} \mathrm{P}$, they are much higher than that of $\mathrm{MoS}_{2}$. Among as-prepared three hybrids, $\mathrm{MoS}_{2} / \mathrm{Ni}_{2} \mathrm{P}-50$ exhibits the best HER performance, which may be due to its uniform morphology, large specific surface area, and excellent stability. The $\mathrm{MoS}_{2} / \mathrm{Ni}_{2} \mathrm{P}-50$ hybrid shows a high cathodic current density $\left(70 \mathrm{~mA} / \mathrm{cm}^{2}\right.$ at $\left.-0.48 \mathrm{~V}\right)$, small Tafel slope $(\sim 58 \mathrm{mV} /$ decade), and a low charge transfer resistance $\left(0.83 \mathrm{k} \Omega \cdot \mathrm{cm}^{2}\right)$.
\end{abstract}

Keywords: hydrogen evolution reaction; molybdenum disulfide; nickel phosphide; hydrothermal synthesis; density functional theory; alkaline electrolyte

\section{Introduction}

With growing concerns about environmental pollution and energy crises resulting from overconsumption of coal and fossil fuels, the exploitation of renewable clean energies, such as solar energy, wind energy, hydraulic power, biological energy, fuel cell, and hydrogen energy come to the forefront [1-3]. Among the clean energies mentioned above, hydrogen energy is attracting ever-growing attention due to the convenient production and effective cost [4,5]. Apart from the traditional method through steam from fossil fuels, the process of electrochemical water splitting is considered as an alternative to produce hydrogen through the HER [6-9]. Until the present, the well-known platinum and platinum-based alloys show the best electrocatalytic performance for HER [10-13]. However, their high-cost and scarcity impede their wide applications in practice [14-16].

To facilitate HER application, it is urgent to develop low-cost alternatives with Earth-abundant and cost-effective features to replace the noble metals $[17,18]$. Thus, various non-noble materials including transition metal sulfides [19], selenides [20], oxides [21], carbides [22], and nitrides [23], 
as well as phosphides [24], have been reported as electrocatalysts for HER. Among these catalysts, $\mathrm{MoS}_{2}$-based materials have been researched as the promising substitutes owing to their low cost, Earth-abundance, and the relatively high activity $[25,26]$. However, the inert basal surface, poor intrinsic conductivity, and insufficient edged activity sites limit their HER performance [27]. In order to enhance the HER performance of this catalyst efficiently, a large number of efforts have been devoted and can be briefly classified as follows [4,28,29]: (1) increasing the density of active edge sites; (2) enhancing the inherent activity; (3) improving the electrical contact between active sites. Generally, intensive endeavors such as interlayer intercalation [30,31], phase transformation (from $2 \mathrm{H}-\mathrm{MoS}_{2}$ to $1 \mathrm{~T}-\mathrm{MoS}_{2}$ ) [32], gentle oxidation [33], functional structural design [34], and stabilizing the edge layers with organic molecules [35] have been made to increase the active sites located at the edge, whereas the basal plane is still chemically inert.

Additionally, for the purpose of improving the electrical contact between active sites of $\mathrm{MoS}_{2}$, various promoters, such as gold [30], platinum [36], palladium [37], carbon materials [38], core-shell $\mathrm{MoO}_{3}$ [39], $\mathrm{Co}_{3} \mathrm{O}_{4}$ nanosheet array [40], graphene [41,42], graphene oxide [17,43], and nickel-phosphorus (Ni-P) powders [4], have been adopted as electrical conduction-enhancing supports. Of all the above-mentioned supports, the cost-effective Ni-P powder possesses superior electrical conductivity and outstanding HER performance [28,44,45]. Thus, this material is a suitable candidate employed to enhance the HER activity of $\mathrm{MoS}_{2}$. In view of the fact that Ni-P incorporation is advantageous to the enhancement in the HER property of $\mathrm{MoS}_{2}$ [4], herein, it should be worth noting that the coexistent nickel phosphide phases (i.e., $\mathrm{Ni}_{5} \mathrm{P}_{2}, \mathrm{Ni}_{2} \mathrm{P}, \mathrm{Ni}_{3} \mathrm{P}, \mathrm{Ni}_{12} \mathrm{P}_{5}, \mathrm{NiP}_{2}, \mathrm{Ni}_{5} \mathrm{P}_{4}, \mathrm{NiP}$, and $\mathrm{Ni}_{7} \mathrm{P}_{3}$ ) [46] will play a major role in HER feature of this catalyst. Among these nickel phosphides, $\mathrm{Ni}_{2} \mathrm{P}$ demonstrates an excellent HER characteristic [14,47] and draws tremendous attention. Although the attempt of incorporation of $\mathrm{Ni}_{2} \mathrm{P}$ on to the surface of nano- $\mathrm{MoS}_{2}$ has been made in the hope of the increment in HER performance [16]; to the best of our knowledge so far, the effort of $\mathrm{Ni}_{2} \mathrm{P}$ employed as a sublayer support to improve the HER property of $\mathrm{MoS}_{2}$ is insufficient. In this sense, the role of $\mathrm{Ni}_{2} \mathrm{P}$ as a layer support in pursuit of the increase in $\mathrm{MoS}_{2}$ HER deserves to be investigated.

Unambiguously, the density functional theory (DFT) calculations as a major supplement to experimental techniques will be significantly valuable for revealing the intrinsic feature of HER [30,42,48-50]. Atomistic details related to the adsorption and desorption of hydrogen atoms, as well as the immanent interaction between hydrogen atom and the catalyst can be perfectly interpreted. To date, some studies in HER process for $\mathrm{MoS}_{2}, \mathrm{Ni}_{2} \mathrm{P}$, and $\mathrm{MoS}_{2}$ /graphene catalysts have been reported $[42,49,50]$, but efforts related to that of $\mathrm{MoS}_{2} /$ graphene hybrid catalyst via the DFT simulation are insufficient.

In this work, $\mathrm{MoS}_{2}$ was anchored on the surface of the $\mathrm{Ni}_{2} \mathrm{P}$ nanosheet via a hydrothermal synthesis process, and the three $\mathrm{MoS}_{2} / \mathrm{Ni}_{2} \mathrm{P}$ hybrids $\left(38 \mathrm{wt} \% \mathrm{Ni}_{2} \mathrm{P}\right.$ addition for $\mathrm{MoS}_{2} / \mathrm{Ni}_{2} \mathrm{P}-38$, 50 wt $\% \mathrm{Ni}_{2} \mathrm{P}$ addition for $\mathrm{MoS}_{2} / \mathrm{Ni}_{2} \mathrm{P}-50$, and 58 wt $\% \mathrm{Ni}_{2} \mathrm{P}$ addition for $\mathrm{MoS}_{2} / \mathrm{Ni}_{2} \mathrm{P}-58$ ) were fabricated. The aim of this study is to offer an effective route to improve the HER property of $\mathrm{MoS}_{2}$ by combining of this metal sulfide with $\mathrm{Ni}_{2} \mathrm{P}$. Morphologies, crystallinities, chemical components, and active areas of the prepared $\mathrm{MoS}_{2} / \mathrm{Ni}_{2} \mathrm{P}$ hybrids were characterized by $\mathrm{X}$-ray diffraction (XRD), scanning electron microscopy (SEM), transmission electron microscopy (TEM), X-ray photoelectron spectroscopy (XPS), and the Brunauer-Emmett-Teller (BET) method. Techniques of linear sweep voltammetry (LSV), Tafel polarization, cyclic voltammetry (CV), and electrochemical impedance spectroscopy (EIS) were employed to test HER properties of the above three hybrids; subsequently, the effect of $\mathrm{Ni}_{2} \mathrm{P}$ as the bottom substrate was illustrated. Additionally, the adsorption energies $\left(\Delta E_{\mathrm{ads}}\right)$ and the Gibbs free energies of adsorption $\left(\Delta G_{\text {ads }}\right)$ between the hydrogen atoms and the catalyst were calculated. Furthermore, the stability of the hybrid was evaluated. 


\section{Experimental Section}

\subsection{Material}

Analytical grade reagents of ammonium molybdate tetrahydrate $\left(\left(\mathrm{NH}_{4}\right)_{6} \mathrm{Mo}_{7} \mathrm{O}_{24} \cdot 4 \mathrm{H}_{2} \mathrm{O}, 99 \mathrm{wt} \%\right)$, thiourea $\left(\mathrm{CH}_{4} \mathrm{~N}_{2} \mathrm{~S}, 99 \mathrm{wt} \%\right)$, red phosphorus, nickel chloride hexahydrate $\left(\mathrm{NiCl}_{2} \cdot 6 \mathrm{H}_{2} \mathrm{O}, 98 \mathrm{wt} \%\right)$, potassium hydroxide $(\mathrm{KOH})$, and absolute ethanol were purchased from Jingchun Scientific Co. Ltd. (Shanghai, China). The 5 wt \% of Nafion solution was offered by Alfa Aesar Chemicals Co. Ltd. (Shanghai, China). The Pt/C power (20 wt \% Pt on Vulcan XC-72R) was supplied by Yu Bo Biotech Co. Ltd. (Shanghai, China). In this present study, all above reagents were used as received in the present study and without further purification.

\subsection{Synthesis of the $\mathrm{Ni}_{2} \mathrm{P}$ Nanosheet}

Under vigorous stirring condition, $1.63 \mathrm{~g}$ red phosphorus and $1.25 \mathrm{~g} \mathrm{NiCl}_{2} \cdot 6 \mathrm{H}_{2} \mathrm{O}$ were dissolved in $15 \mathrm{~mL}$ deionized water for $30 \mathrm{~min}$ and a slurry-like mixture was obtained. Then this mixture solution was transferred into a $25 \mathrm{~mL}$ Teflon-lined stainless steel autoclave and followed by placed into a muffle furnace (WRN-010, Eurasian, Tianjin, China), which was preheated to $180{ }^{\circ} \mathrm{C}$. The hydrothermal synthesis process was carried out at $180{ }^{\circ} \mathrm{C}$ for $24 \mathrm{~h}$. When the temperature of the muffle furnace was cooled to room temperature naturally, the formed particles were separated by centrifugation and washed with ethanol twice and deionized water three times. Lastly, the fabricated gray-black $\mathrm{Ni}_{2} \mathrm{P}$ powders were dried in a vacuum oven (DZF-6050, Boxun Industrial Co. Ltd., Shanghai, China) and retained for use.

\subsection{Synthesis of the $\mathrm{MoS}_{2} / \mathrm{Ni}_{2} \mathrm{P}$ Hybrids}

A total of $1.41 \mathrm{~g}\left(\mathrm{NH}_{4}\right)_{6} \mathrm{Mo}_{7} \mathrm{O}_{24} \cdot 4 \mathrm{H}_{2} \mathrm{O}, 0.26 \mathrm{~g} \mathrm{CH}_{4} \mathrm{~N}_{2} \mathrm{~S}$ and three different amounts of $\mathrm{Ni}_{2} \mathrm{P}$ (38 wt \%, $50 \mathrm{wt} \%$, and $58 \mathrm{wt} \%$ ) were dispersed in $20 \mathrm{~mL}$ of distilled water. The mixture solution was vigorously stirred for $1 \mathrm{~h}$ at room temperature. After that, the solution was transferred into a $25 \mathrm{~mL}$ Teflon-lined stainless steel autoclave placed in a muffle furnace, and then reacted at $200{ }^{\circ} \mathrm{C}$ for $24 \mathrm{~h}$. As the solution temperature was cooled to room temperature naturally, the resultant three black samples $\left(\mathrm{MoS}_{2} / \mathrm{Ni}_{2} \mathrm{P}-38, \mathrm{MoS}_{2} / \mathrm{Ni}_{2} \mathrm{P}-50\right.$, and $\left.\mathrm{MoS}_{2} / \mathrm{Ni}_{2} \mathrm{P}-58\right)$ were centrifuged and adequately washed with ethanol and deionized water. Finally, the as-synthesized samples were dried under a vacuum atmosphere at $60{ }^{\circ} \mathrm{C}$ for $12 \mathrm{~h}$.

\subsection{Characterization}

Crystal structures of the synthesized $\mathrm{MoS}_{2} / \mathrm{Ni}_{2} \mathrm{P}$ samples were determined by an $\mathrm{X}$-ray diffractometer (XRD, SmartLab, Tokyo, Japan) using $\mathrm{Cu} \mathrm{K} \alpha$ radiation $(\lambda=1.5418 \AA)$ from 5 to 100 angles at a scanning rate of $5^{\circ} / \mathrm{min}$. The morphologies of the samples were obtained using a scanning electron microscope (SEM, S-4800, Hitachi, Tokyo, Japan) at an accelerating voltage of $5 \mathrm{kV}$. The elemental compositions and chemical states of these three $\mathrm{MoS}_{2} / \mathrm{Ni}_{2} \mathrm{P}$ samples were characterized by X-ray photoelectron spectra (XPS, ESCALAB MK II, Thermo Fisher Scientific, Waltham, MA, USA) using $\mathrm{Mg} \mathrm{K} \alpha$ as the excitation source. The Brunauer-Emmett-Teller (BET) specific surface areas of the obtained samples were examined by $\mathrm{N}_{2}$ adsorption/desorption measurement on a Nova 4000e analyzer (Quantachrome Instrument, Boynton Beach, FL, USA) at $77 \mathrm{~K}$.

\subsection{Electrochemical Measurements}

Before preparing the working electrode, a glassy carbon electrode (GCE) of $3 \mathrm{~mm}$ in diameter was firstly polished with 1000\# water sandpaper and cleaned with ethanol and deionized water. Typically, $5 \mathrm{mg}$ of catalyst $\left(\mathrm{Ni}_{2} \mathrm{P}, \mathrm{MoS}_{2}, \mathrm{MoS}_{2} / \mathrm{Ni}_{2} \mathrm{P}\right.$ hybrids, and the commercial $\left.20 \mathrm{wt} \% \mathrm{Pt} / \mathrm{C}\right)$ and $30 \mu \mathrm{L}$ Nafion solution ( $5 \mathrm{wt} \%$ ) were dispersed in $1 \mathrm{~mL}$ solution consisting of $250 \mu \mathrm{L}$ absolute ethanol and $750 \mu \mathrm{L}$ deionized water, and followed by sonication for $1 \mathrm{~h}$ to form a homogeneous ink. Then, $5 \mu \mathrm{L}$ of the 
dispersion solution was loaded onto the surface of the polished GCE and the electrode was dried at room temperature; herein, the excessive ethanol present in the slurry was removed as much as possible by extending the drying time. Prior to each electrochemical test, the electrolyte solution was degassed by bubbling pure nitrogen gas for $30 \mathrm{~min}$ to remove the dissolved oxygen.

All electrochemical tests were conducted in a typical three-electrode system attached to an electrochemical workstation (CHI 650C, Chenhua Co. Ltd., Shanghai, China) in $1.0 \mathrm{~mol} / \mathrm{L} \mathrm{KOH}$ electrolyte. The GCE modified by the $\mathrm{MoS}_{2} / \mathrm{Ni}_{2} \mathrm{P}$ hybrids $\left(\mathrm{MoS}_{2}, \mathrm{Ni}_{2} \mathrm{P}\right.$ or Pt/C) acted as the working electrode, while a $\mathrm{Ag} / \mathrm{AgCl}$ electrode and a platinum foil were employed as the reference and counter electrodes, respectively. The acquired potential values relevant to the $\mathrm{Ag} / \mathrm{AgCl}$ electrode were converted to the reversible hydrogen electrode (RHE) scale: $E_{\mathrm{RHE}}=E_{\mathrm{Ag} / \mathrm{AgCl}}+0.059 \mathrm{pH}+0.209 \mathrm{~V}$, i.e., the value of potential throughout this manuscript is relative to RHE. Linear sweep voltammetry (LSV) was analyzed in the potential of -0.8 to $0.2 \mathrm{~V}$ at a scan rate of $2 \mathrm{mV} / \mathrm{s}$. Tafel polarization curves were measured in a potential window of $0.3-0.65 \mathrm{~V}$ with a scan rate of $2 \mathrm{mV} / \mathrm{s}$. Cyclic voltammetry $(\mathrm{CV})$ tests were conducted in a potential window from -0.6 to $0.8 \mathrm{~V}$ at a scan rate of $10 \mathrm{mV} / \mathrm{s}$. The electrochemical impedance spectroscopy (EIS) measurements were carried out at a cathodic overpotential of $0.7 \mathrm{~V}$ by employing the sinusoidal signal amplitude of $5 \mathrm{mV}$; the frequency ranged from $10^{5}$ to $0.01 \mathrm{~Hz}$.

\subsection{Computational Details}

The calculations based on DFT were implemented in the Materials Studio $\mathrm{DMol}^{3}$ (version 7.0, Accelrys Inc., San Diego, CA, USA) [50,51]. Pulay's direct inversion in the iterative subspace (DIIS) technique, as well as double numerical plus polarization functions (DNP) and the revised Perdew-Burke-Ernzerhof (RPBE) functional were employed. The effective core potential was applied to treat the core electrons of nickel atoms. With respect to the aqueous HER process, a continuum solvation model (COSMO) was used and water with the dielectric constant of 78.54 as the solvent [52]. In addition, for the purpose of taking into account of the weak interactions (hydrogen bond and van der Waals force), the TS (Tkatchenko-Scheffler) method for DFT-D correction was employed [52].

As is well known, the basal plane of $\mathrm{MoS}_{2}$ has been validated as chemically inert, thus, only the Mo edge-type structure of this catalyst was considered [30]. Three kinds of geometries for $\mathrm{MoS}_{2}$, $\mathrm{Ni}_{2} \mathrm{P}$, and $\mathrm{MoS}_{2} / \mathrm{Ni}_{2} \mathrm{P}$ catalysts were employed: a $(4 \times 5 \times 1)$ supercell with two S-Mo-S trilayer for $\mathrm{MoS}_{2}$, a $(2 \times 1 \times 1)$ supercell derived from $\mathrm{Ni}_{2} \mathrm{P}(111)$ crystal surface with four layers, and a single $(4 \times 5 \times 1)$-sized trilayer $\mathrm{MoS}_{2}$ combined by three $(2 \times 1 \times 1)$-sized $\mathrm{Ni}_{2} \mathrm{P}$ layers for $\mathrm{MoS}_{2} / \mathrm{Ni}_{2} \mathrm{P}$. A vacuum with the thickness of $15 \AA$ in the z-direction was used to separate neighboring slabs and to minimize the interactions between them. During the calculations, only the first layers of $\mathrm{MoS}_{2}$ and $\mathrm{Ni}_{2} \mathrm{P}$ were relaxed in order to save time and computational cost.

\section{Results and Discussion}

\subsection{Characterization of Samples}

\subsubsection{X-ray Diffraction (XRD) Analysis}

The XRD patterns of $\mathrm{MoS}_{2}, \mathrm{Ni}_{2} \mathrm{P}$, and three $\mathrm{MoS}_{2} / \mathrm{Ni}_{2} \mathrm{P}$ hybrids $\left(\mathrm{MoS}_{2} / \mathrm{Ni}_{2} \mathrm{P}-38, \mathrm{MoS}_{2} / \mathrm{Ni}_{2} \mathrm{P}-50\right.$, and $\left.\mathrm{MoS}_{2} / \mathrm{Ni}_{2} \mathrm{P}-58\right)$ are displayed in Figure 1. The characteristics peaks at $2 \theta=33.8^{\circ}$ and $57.1^{\circ}$ (curve 1) can be identified, corresponding to (100) and (110) crystal planes of $\mathrm{MoS}_{2}$, respectively. Herein, it should be noted that the diffraction peak of (002) plane of $\mathrm{MoS}_{2}$ is undetected. The absence of the (002) diffraction peak of $\mathrm{MoS}_{2}$ indicates a low stacking height along this direction [5,53]. As demonstrated in curve 2 , the diffraction peaks at $2 \theta=40.71^{\circ}, 44.61^{\circ}, 47.34^{\circ}, 54.19^{\circ}, 54.96^{\circ}, 66.37^{\circ}, 72.4^{\circ}, 74.9^{\circ}, 80.5^{\circ}$, and $88.6^{\circ}$ corresponding to (111), (201), (210), (300), (211), (310), (311), (400), (401), and (321) confirm the presence of hexagonal $\mathrm{Ni}_{2} \mathrm{P}$; besides the above-mentioned peaks, the detectable weak peaks $\left(2 \theta=30.36^{\circ}, 31.58^{\circ}\right)$ may be attributed to the coexistence of $\mathrm{Ni}_{5} \mathrm{P}_{4}$ phase [54], and another weak peak at 
$2 \theta=35.4^{\circ}$ can be assigned to the presence of $\mathrm{Ni}_{12} \mathrm{P}_{5}$ phase [55]. XRD patterns of the $\mathrm{MoS}_{2} / \mathrm{Ni}_{2} \mathrm{P}$ hybrids are presented in curves 3-5. The diffraction patterns of $\mathrm{MoS}_{2} / \mathrm{Ni}_{2} \mathrm{P}$ hybrids consist of very weak diffraction peak of $\mathrm{MoS}_{2}$, which indicates that the $\mathrm{MoS}_{2}$ is amorphous [5]. In addition, the diffraction peaks related to $\mathrm{MoS}_{2}$ and $\mathrm{Ni}_{2} \mathrm{P}$ are observed, thus suggesting the successful combination between $\mathrm{MoS}_{2}$ and $\mathrm{Ni}_{2} \mathrm{P}$. It may be indexed to a proof of the fabrication of $\mathrm{MoS}_{2} / \mathrm{Ni}_{2} \mathrm{P}$ hybrid. Compared with pure $\mathrm{Ni}_{2} \mathrm{P}$, the diffraction intensity of $\mathrm{Ni}_{2} \mathrm{P}$ crystal for three $\mathrm{MoS}_{2} / \mathrm{Ni}_{2} \mathrm{P}$ hybrids becomes weak. However, with the increase of $\mathrm{Ni}_{2} \mathrm{P}$ addition, intensities of diffraction peaks attributed to $\mathrm{Ni}_{2} \mathrm{P}$ become strong and those of $\mathrm{MoS}_{2}$ show a descending trend, which indicates that $\mathrm{Ni}_{2} \mathrm{P}$ plays a major role in the crystallinity of the hybrids.

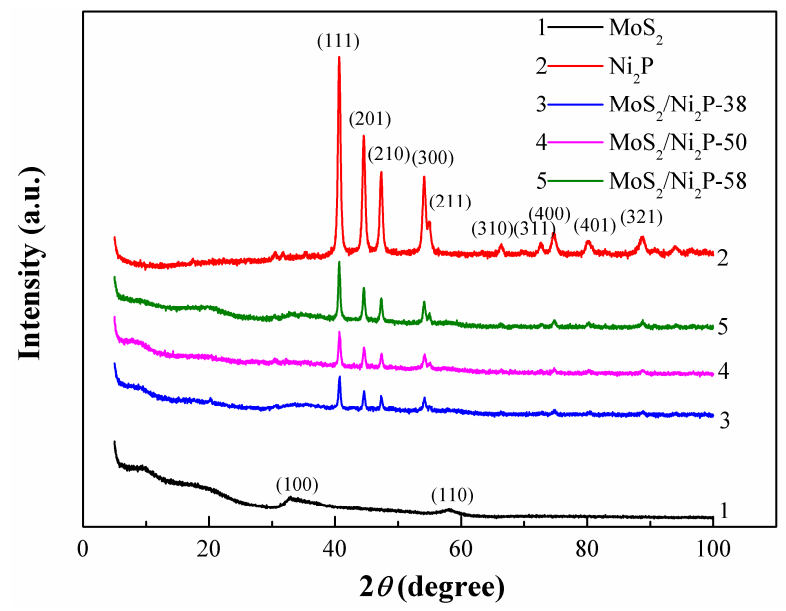

Figure 1. XRD patterns of $\mathrm{MoS}_{2}, \mathrm{Ni}_{2} \mathrm{P}$, and three $\mathrm{MoS}_{2} / \mathrm{Ni}_{2} \mathrm{P}$ hybrids.

\subsubsection{Scanning Electron Microscope (SEM)}

The morphologies of $\mathrm{MoS}_{2}, \mathrm{Ni}_{2} \mathrm{P}$, and three $\mathrm{MoS}_{2} / \mathrm{Ni}_{2} \mathrm{P}$ hybrids are given in Figure 2. As shown in Figure 2a, the nanoflower-like structure of $\mathrm{MoS}_{2}$ can be ascertained; of course, there are some nanosheets randomly stacking, which may lead to the decrease in active sites. The fabricated $\mathrm{Ni}_{2} \mathrm{P}$ particle exhibits a nanosheet-type morphology (Figure 2b), which would be advantageous to electrochemical conduction among the active sites. Morphologies of the three hybrids are observed in Figure $2 \mathrm{c}\left(\mathrm{MoS}_{2} / \mathrm{Ni}_{2} \mathrm{P}-38\right), 2 \mathrm{~d}\left(\mathrm{MoS}_{2} / \mathrm{Ni}_{2} \mathrm{P}-50\right)$ and $2 \mathrm{e}\left(\mathrm{MoS}_{2} / \mathrm{Ni}_{2} \mathrm{P}-58\right)$. All of them exhibit a mixed morphology of flower-like and lamellar structures.

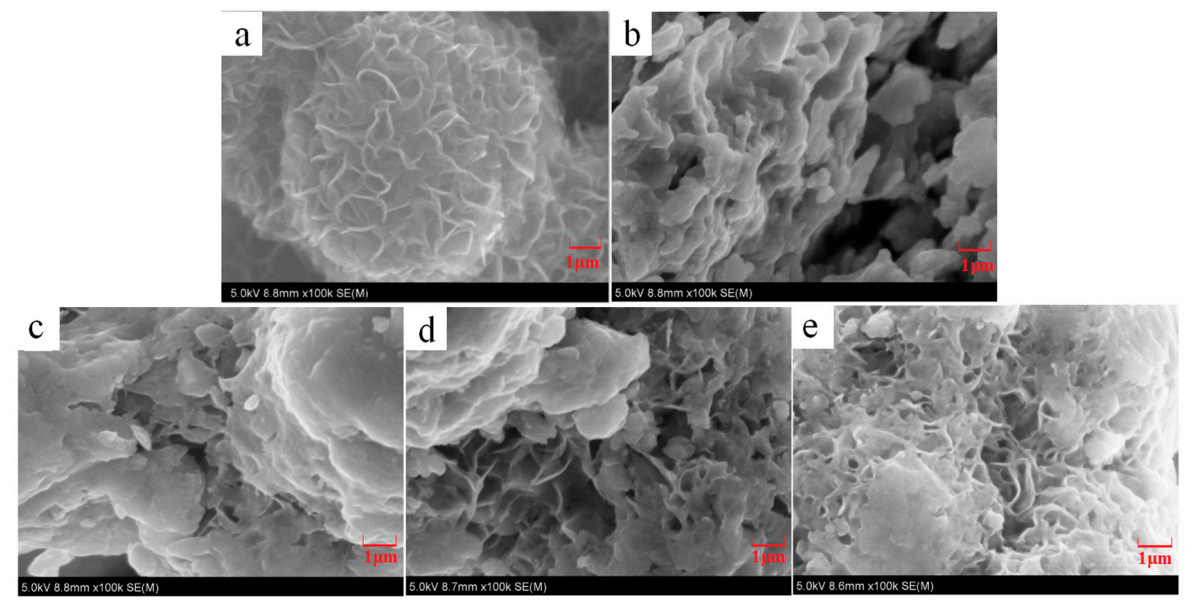

Figure 2. SEM images of $\mathrm{MoS}_{2}, \mathrm{Ni}_{2} \mathrm{P}$, and three $\mathrm{MoS}_{2} / \mathrm{Ni}_{2} \mathrm{P}$ hybrids: (a) $\mathrm{MoS}_{2} ;$ (b) $\mathrm{Ni}_{2} \mathrm{P}$; (c) $\mathrm{MoS}_{2} / \mathrm{Ni}_{2} \mathrm{P}-38$; (d) $\mathrm{MoS}_{2} / \mathrm{Ni}_{2} \mathrm{P}-50$; and (e) $\mathrm{MoS}_{2} / \mathrm{Ni}_{2} \mathrm{P}-58$. 
As for the SEM pictures of hybrids, with the increasing addition of $\mathrm{Ni}_{2} \mathrm{P}$, the flower-shaped structure can be more easily observed, the presence of the $\mathrm{Ni}_{2} \mathrm{P}$ nanosheet will be helpful for the fabrication of $\mathrm{MoS}_{2}$ nanoflowers. For the sample of $\mathrm{MoS}_{2} / \mathrm{Ni}_{2} \mathrm{P}-38$, the small amount of $\mathrm{Ni}_{2} \mathrm{P}$ cannot provide an abundant depositing area, thereby resulting in the serious agglomeration of $\mathrm{MoS}_{2}$ (Figure 2c). For $\mathrm{MoS}_{2} / \mathrm{Ni}_{2} \mathrm{P}-50$ sample (the mass ratio of $\mathrm{MoS}_{2}$ and $\mathrm{Ni}_{2} \mathrm{P}$ is $1: 1$ ), it can be observed that the petal structure and the plate-type structure uniformly coexist (Figure 2d), and more well-proportioned nanoflower-like $\mathrm{MoS}_{2}$ particles distribute on the surface of $\mathrm{Ni}_{2} \mathrm{P}$. Whereas, for $\mathrm{MoS}_{2} / \mathrm{Ni}_{2} \mathrm{P}-58$ (Figure 2e), with the large addition of $\mathrm{Ni}_{2} \mathrm{P}$, it is explicit that the dense $\mathrm{MoS}_{2}$ flower structure can be obtained, showing a resemblance to that of $\mathrm{MoS}_{2}$ (Figure 2a). By a comparison of morphologies of the three hybrids, for the $\mathrm{MoS}_{2} / \mathrm{Ni}_{2} \mathrm{P}-50$ sample, the $\mathrm{MoS}_{2}$ nanoparticles evenly disperses on the surface of the $\mathrm{Ni}_{2} \mathrm{P}$ nanosheet.

\subsubsection{X-ray Photoelectron Spectroscopy (XPS)}

The elemental compositions and their valences of three $\mathrm{MoS}_{2} / \mathrm{Ni}_{2} \mathrm{P}$ hybrids were measured by XPS. The Mo 3d, S 2p, Ni 2p, P 2p and O 1s high-resolution spectra of three $\mathrm{MoS}_{2} / \mathrm{Ni}_{2} \mathrm{P}$ hybrids are respectively presented in Figure 3, and the corresponding bond energies and assignments are given in Table 1. As shown in Figure 3a, the characteristic peaks located at $229.0 \mathrm{eV}$ and $231.9 \mathrm{eV}$ (take $\mathrm{MoS}_{2} / \mathrm{Ni}_{2} \mathrm{P}-38$ as an example, the following is the same) can be assigned to Mo $3 \mathrm{~d}_{5 / 2}$ and $\mathrm{Mo}_{3} 3 \mathrm{~d}_{3 / 2}$ respectively, suggesting the existence of $\mathrm{Mo}^{4+}$. The two peaks at $232.9 \mathrm{eV}$ and $236.0 \mathrm{eV}$ are ascribed to the compounds $\mathrm{MoO}_{3}$ or $\mathrm{MoO}_{4}{ }^{2-}\left(\mathrm{Mo}^{6+}\right)$ due to the oxidation of the samples. In addition, the weak peak appearing at $226.4 \mathrm{eV}$ corresponds to $\mathrm{S} 2 \mathrm{~s}$ of $\mathrm{MoS}_{2}$ [56]. For S 2p spectra, which is shown in Figure $3 \mathrm{~b}$, the two peaks at $161.8 \mathrm{eV}$ and $163.3 \mathrm{eV}$ are attributed to the $2 \mathrm{p}_{3 / 2}$ and $2 \mathrm{p}_{1 / 2}$ orbitals of divalent sulfide ion $\left(\mathrm{S}^{2-}\right)$, while the other two peaks at $168.9 \mathrm{eV}$ and $170.0 \mathrm{eV}$ represent the existence of tetravalent sulfur in the form of $\mathrm{SO}_{3}{ }^{2-}\left(\mathrm{S}^{4+}\right)$. Generally, the sulphur atom with a +4 state locates at the edge of $\mathrm{MoS}_{2}$ layered structure due to the oxidation of $\mathrm{MoS}_{2}$ particle [57].
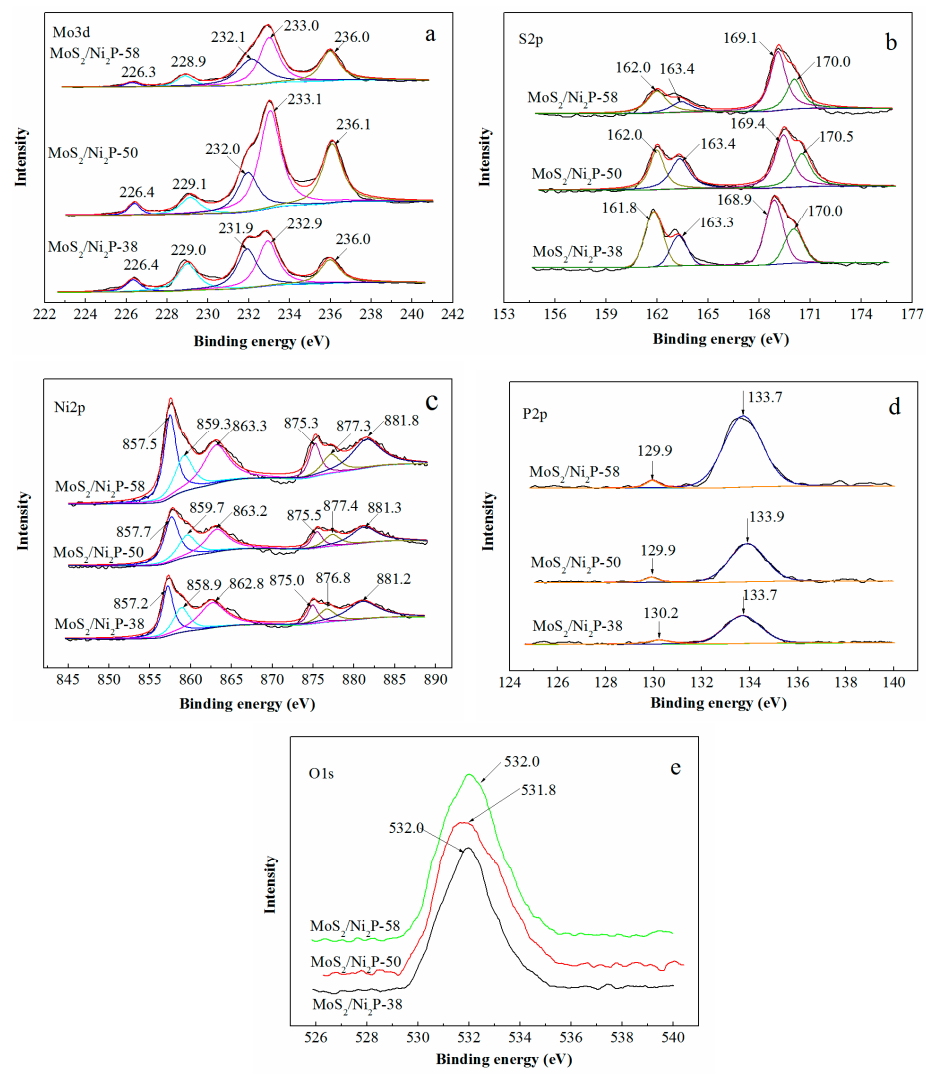

Figure 3. XPS spectra of three $\mathrm{MoS}_{2} / \mathrm{Ni}_{2} \mathrm{P}$ hybrids: (a) Mo 3d; (b) S 2p; (c) Ni 2p; (d) P 2p; and (e) O 1s. 
As shown in Figure 3c, the three peaks observed at $857.2 \mathrm{eV}, 858.9 \mathrm{eV}$ and $862.8 \mathrm{eV}$ may be assigned to $\mathrm{Ni}^{\delta+}(0<\delta<2)$ in $\mathrm{Ni}_{2} \mathrm{P}$, oxidized $\mathrm{Ni}$ species $\left(\mathrm{Ni}^{2+}\right)$ and the satellite of $\mathrm{Ni} 2 \mathrm{p}_{3 / 2}$, respectively, while the other three peaks at $875.0 \mathrm{eV}, 876.8 \mathrm{eV}$, and $881.2 \mathrm{eV}$ can be indexed to $\mathrm{Ni}^{\delta+}$ in $^{\mathrm{Ni}}{ }_{2} \mathrm{P}$, oxidized $\mathrm{Ni}$ species, and the satellite of $\mathrm{Ni} 2 \mathrm{p}_{1 / 2}$ [58]. As for the P $2 \mathrm{p}$ spectra (Figure $3 \mathrm{~d}$ ), the peak at $130.2 \mathrm{eV}$ is mark of metal-P bonds in metal phosphides, the peak at $133.7 \mathrm{eV}$ can be assumed to the oxidized $\mathrm{P}$ species because the samples are exposed to the air [59].

Additionally, the $\mathrm{O}$ 1s peak (Figure 3e), with the binding energies of $532.0 \mathrm{eV}$, indicates the existence of $\mathrm{Mo}(\mathrm{IV})-\mathrm{O}$ bond [60]. Thus, to some extent, it is also confirmed that the three hybrids were oxidized during the preparation process.

Table 1. Bond energies and assignments of Mo 3d, S 2p, Ni 2p, P 2p, and O 1s photoelectron peaks of three $\mathrm{MoS}_{2} / \mathrm{Ni}_{2} \mathrm{P}$ hybrids.

\begin{tabular}{|c|c|c|c|c|c|}
\hline $\begin{array}{c}\text { Bond } \\
\text { Energies/(eV) }\end{array}$ & $\mathrm{MoS}_{2} / \mathrm{Ni}_{2} \mathrm{P}-38$ & $\mathrm{MoS}_{2} / \mathrm{Ni}_{2} \mathrm{P}-50$ & $\mathrm{MoS}_{2} / \mathrm{Ni}_{2} \mathrm{P}-58$ & Assignments & References \\
\hline \multirow{5}{*}{ Mo 3d } & 229.0 & 229.1 & 228.9 & $\mathrm{Mo}^{4+}$ & \multirow{5}{*}{ [56] } \\
\hline & 231.9 & 232.0 & 232.1 & $\mathrm{Mo}^{4+}$ & \\
\hline & 232.9 & 233.1 & 233.0 & $\mathrm{Mo}^{6+}$ & \\
\hline & 236.0 & 236.1 & 236.0 & $\mathrm{Mo}^{6+}$ & \\
\hline & 226.4 & 226.4 & 226.3 & S 2s & \\
\hline \multirow{4}{*}{$S 2 p$} & 161.8 & 162.0 & 162.0 & $S^{2-}$ & \multirow{4}{*}{ [57] } \\
\hline & 163.3 & 163.4 & 163.4 & $S^{2-}$ & \\
\hline & 168.9 & 169.4 & 169.1 & $S^{4+}$ & \\
\hline & 170.0 & 170.5 & 170.0 & $\mathrm{~S}^{4+}$ & \\
\hline \multirow{6}{*}{ Ni $2 p$} & 857.2 & 857.7 & 857.5 & $\mathrm{Ni}^{\delta+}(0<\delta<2)$ & \multirow{6}{*}{ [58] } \\
\hline & 858.9 & 859.7 & 859.3 & $\mathrm{Ni}^{2+}$ & \\
\hline & 862.8 & 863.2 & 863.3 & $\mathrm{Ni} 2 \mathrm{p}_{3 / 2}$ & \\
\hline & 875.0 & 875.5 & 875.3 & $\mathrm{Ni}^{\delta+}(0<\delta<2)$ & \\
\hline & 876.8 & 877.4 & 877.3 & $\mathrm{Ni}^{2+}$ & \\
\hline & 881.2 & 881.3 & 881.8 & $\mathrm{Ni} 2 \mathrm{p}_{1 / 2}$ & \\
\hline \multirow{2}{*}{$P 2 p$} & 130.2 & 129.9 & 129.9 & Metal-P & \multirow{2}{*}{ [59] } \\
\hline & 133.7 & 133.9 & 133.7 & $\mathrm{P}-\mathrm{O}$ & \\
\hline O 1s & 532.0 & 531.8 & 532.0 & $\mathrm{Mo}(\mathrm{IV})-\mathrm{O}$ & {$[60]$} \\
\hline
\end{tabular}

\subsection{4. $\mathrm{N}_{2}$ Adsorption/Desorption Isotherm Measurement}

The specific surface areas of the as-synthesized pure $\mathrm{MoS}_{2}, \mathrm{Ni}_{2} \mathrm{P}$, and three $\mathrm{MoS}_{2} / \mathrm{Ni}_{2} \mathrm{P}$ hybrids were characterized by $\mathrm{N}_{2}$ adsorption/desorption isotherm measurement (Figure 4). All curves reveal a type IV isotherm with a distinct hysteresis loop, indicating the mesoporous structures of the above samples. The specific surface areas of aforementioned three hybrids are in a trend: $\mathrm{MoS}_{2} / \mathrm{Ni}_{2} \mathrm{P}-50$ $\left(2.42 \mathrm{~m}^{2} / \mathrm{g}\right)>\mathrm{MoS}_{2} / \mathrm{Ni}_{2} \mathrm{P}-58\left(1.95 \mathrm{~m}^{2} / \mathrm{g}\right)>\mathrm{MoS}_{2} / \mathrm{Ni}_{2} \mathrm{P}-38\left(1.86 \mathrm{~m}^{2} / \mathrm{g}\right)$. The specific surface areas of these three hybrids are smaller than that of pure $\mathrm{Ni}_{2} \mathrm{P}\left(4.62 \mathrm{~m}^{2} / \mathrm{g}\right)$. For pure $\mathrm{MoS}_{2}$, although its specific surface area $\left(7.04 \mathrm{~m}^{2} / \mathrm{g}\right)$ is larger than the other four samples, its basal surface is HER inert, so it cannot provide abundant active sites for hydrogen adsorption, which means an inferior HER property. Among the three hybrids, $\mathrm{MoS}_{2} / \mathrm{Ni}_{2} \mathrm{P}-50$ possess the largest specific surface area, the HER performance of this hybrid will be more outstanding than the other two hybrids. However, its HER characteristic cannot be comparable to that of $\mathrm{Ni}_{2} \mathrm{P}$, because of its smaller determined specific surface area (ca. $52.4 \%$ of that of $\mathrm{Ni}_{2} \mathrm{P}$ ). 

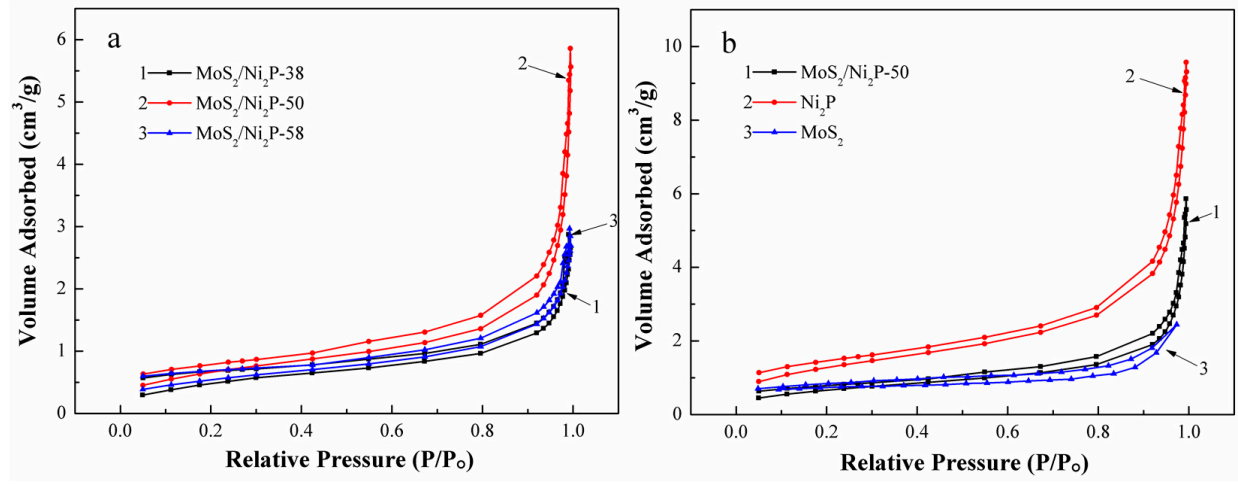

Figure 4. $\mathrm{N}_{2}$ adsorption/desorption curves of the samples: (a) $\mathrm{MoS}_{2} / \mathrm{Ni}_{2} \mathrm{P}-38, \mathrm{MoS}_{2} / \mathrm{Ni}_{2} \mathrm{P}-50$, and $\mathrm{MoS}_{2} / \mathrm{Ni}_{2} \mathrm{P}-58 ;(\mathbf{b}) \mathrm{MoS}_{2} / \mathrm{Ni}_{2} \mathrm{P}-50, \mathrm{Ni}_{2} \mathrm{P}$, and $\mathrm{MoS}_{2}$.

\subsection{Electrochemical Analysis of HER}

\subsubsection{Linear Sweep Voltammetry (LSV)}

The LSV curves of all samples in $1.0 \mathrm{~mol} / \mathrm{L} \mathrm{KOH}$ at a scan rate of $2 \mathrm{mV} / \mathrm{s}$ are depicted in Figure 5 . The obtained onset overpotentials ( $\eta_{\text {onset }}$ ) [61] are tabulated in Table 2. All samples were measured within the potential window of $-0.8 \sim 0.2 \mathrm{~V}$. The pure $\mathrm{MoS}_{2}$ shows the lower HER activity which is attributed to its inert basal surface and inferior conductivity [28]. By contrast, HER performances of the three hybrids are higher than pure $\mathrm{MoS}_{2}$ because of the excellent conductivity and affordable active sites. Although the catalytic performances of three $\mathrm{MoS}_{2} / \mathrm{Ni}_{2} \mathrm{P}$ hybrids are lower than those of $\mathrm{Ni}_{2} \mathrm{P}$ and commercial $\mathrm{Pt} / \mathrm{C}$, they can still raise attention in hydrogen evolution reaction. When the potential was kept at $-0.1 \mathrm{~V}$, the cathodic current density of HER for tested samples is in the following sequence: $\mathrm{MoS}_{2}\left(1.56 \mathrm{~mA} / \mathrm{cm}^{2}\right)<\mathrm{MoS}_{2} / \mathrm{Ni}_{2} \mathrm{P}-38\left(1.86 \mathrm{~mA} / \mathrm{cm}^{2}\right)<\mathrm{MoS}_{2} / \mathrm{Ni}_{2} \mathrm{P}-58\left(2.52 \mathrm{~mA} / \mathrm{cm}^{2}\right)<$ $\mathrm{MoS}_{2} / \mathrm{Ni}_{2} \mathrm{P}-50\left(3.53 \mathrm{~mA} / \mathrm{cm}^{2}\right)<\mathrm{Ni}_{2} \mathrm{P}\left(5.71 \mathrm{~mA} / \mathrm{cm}^{2}\right)<\mathrm{Pt} / \mathrm{C}\left(8.57 \mathrm{~mA} / \mathrm{cm}^{2}\right)$. Herein, it should be mentioned that although $\mathrm{Ni}_{2} \mathrm{P}$ shows a better HER feature than the produced three hybrids, its stability will be worse in an alkaline solution [14]. Among the three hybrids, $\mathrm{MoS}_{2} / \mathrm{Ni}_{2} \mathrm{P}-50$ shows a high cathodic current density $\left(70 \mathrm{~mA} / \mathrm{cm}^{2}\right.$ at $\left.-0.48 \mathrm{~V}\right)$, thus exhibiting the best HER performance. The HER performance of this hybrid might be due to the excellent conductivity, as well as the coexistence of nanosheet-type $\mathrm{Ni}_{2} \mathrm{P}$ crystal on the bottom and nanoflower-like $\mathrm{MoS}_{2}$ on the surface. Without doubt, the incorporation of $\mathrm{Ni}_{2} \mathrm{P}$ brings a great enhancement in HER performance of $\mathrm{MoS}_{2}$.

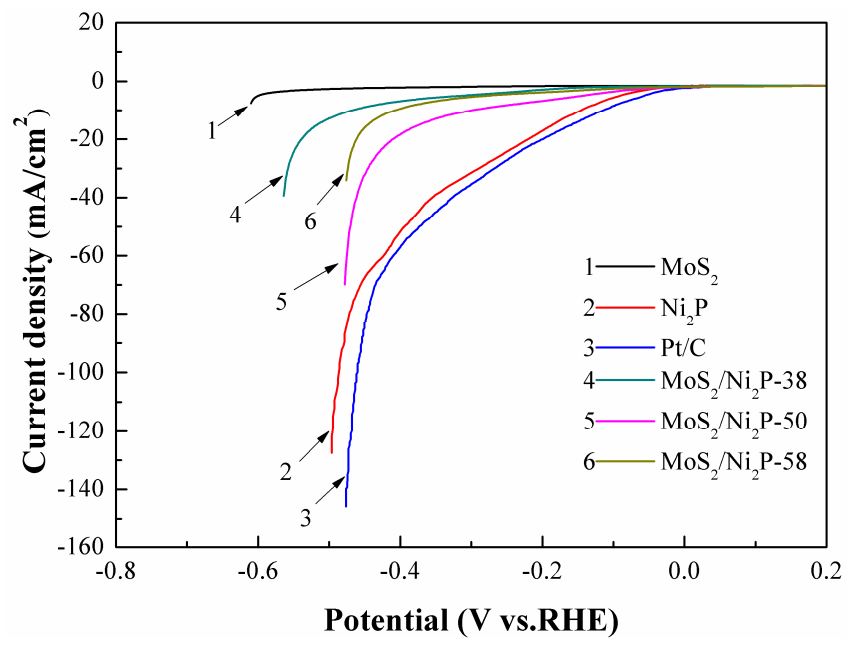

Figure 5. LSV curves of the pure $\mathrm{MoS}_{2}, \mathrm{Ni}_{2} \mathrm{P}$, three $\mathrm{MoS}_{2} / \mathrm{Ni}_{2} \mathrm{P}$ hybrids, and commercial $20 \mathrm{wt} \% \mathrm{Pt} / \mathrm{C}$. Scan rate: $2 \mathrm{mV} / \mathrm{s}$, potential window: $-0.8 \sim 0.2 \mathrm{~V}$ (vs. RHE). 
Table 2. The obtained values of onset overpotentials ( $\left.\eta_{\text {onset }}\right)$, Tafel slope $(b)$, and charge transfer coefficient $(\alpha)$.

\begin{tabular}{cccc}
\hline Samples & $\boldsymbol{\eta}_{\text {onset }} /(\mathbf{m V})$ & $\boldsymbol{b} /(\mathbf{m V} /$ Decade $)$ & $\boldsymbol{\alpha}$ \\
\hline $\mathrm{MoS}_{2}$ & -245 & 128 & 0.46 \\
$\mathrm{Ni}_{2} \mathrm{P}$ & -48 & 49 & 1.21 \\
$20 \mathrm{wt} \% \mathrm{Pt} / \mathrm{C}$ & -25 & 35 & 1.69 \\
$\mathrm{MoS}_{2} / \mathrm{Ni}_{2} \mathrm{P}-38$ & -124 & 102 & 0.58 \\
$\mathrm{MoS}_{2} / \mathrm{Ni}_{2} \mathrm{P}-50$ & -86 & 58 & 1.02 \\
$\mathrm{MoS}_{2} / \mathrm{Ni}_{2} \mathrm{P}-58$ & -111 & 70 & 0.84 \\
\hline
\end{tabular}

\subsubsection{Tafel Polarization}

Equation (1) was employed to describe the relationship of overpotential $(\eta, \mathrm{V})$ and current density $\left(j, \mathrm{~mA} / \mathrm{cm}^{2}\right)$; the charge transfer coefficient $(\alpha)$ can be obtained by Equation (2) [62]:

$$
\begin{gathered}
\eta=b \times \log j+A \\
b=\frac{2.303 R T}{m_{e} \alpha F}
\end{gathered}
$$

where $b$ and $R$ are the Tafel slope ( $\mathrm{mV} /$ decade) and gas constant $(8.314 \mathrm{~J} /(\mathrm{K} \cdot \mathrm{mol}))$, respectively. $A$ is an analyzed constant, $T$ is the absolute temperature, $m_{\mathrm{e}}$ is number of electrons transferred, and $F$ is the Faraday constant $(96,485 \mathrm{C} / \mathrm{mol})$. According to published studies [12,13], the HER in alkaline solutions is typically considered as the Volmer-Heyrovsky process or Volmer-Tafel pathways, they are depicted as follows:

$$
\begin{gathered}
\text { Volmer reaction: } \mathrm{H}_{2} \mathrm{O}+\mathrm{e} \rightarrow \mathrm{H}_{\mathrm{ads}}+\mathrm{OH}^{-} \\
\text {Heyrovsky reaction: } \mathrm{H}_{\mathrm{ads}}+\mathrm{H}_{2} \mathrm{O}+\mathrm{e} \rightarrow \mathrm{H}_{2}+\mathrm{OH}^{-} \\
\text {Tafel reaction: } \mathrm{H}_{\mathrm{ads}}+\mathrm{H}_{\mathrm{ads}} \rightarrow \mathrm{H}_{2}
\end{gathered}
$$

The kinetic mechanism in the HER process is determined by the rate-determining step (rds) of a multi-step reaction. The Tafel equation can play an important role in estimating the kinetic mechanism. The parameter of $\alpha$ corresponds to the rds for multi-step reactions, this is depicted as follows: the value of $\alpha$ is $\sim 0.5$ when the rds is Volmer reaction step, the value of $\alpha$ is $\sim 1.5$ when the rds is Heyrovsky reaction step, and the value of $\alpha$ will be close to 2 when the rds is step Tafel reaction $[63,64]$. Additionally, the Tafel slope is an important factor to describe the HER rate by examining the change of current density with overpotential. Generally, a small Tafel slope is desirable to drive a large catalytic current density at low overpotentials [65]. The Tafel plots of these samples derived from the polarization curves are shown in Figure 6. The HER performance of $\mathrm{MoS}_{2}$ is inferior due to its large Tafel slope ( $128 \mathrm{mV} /$ decade) and small $\alpha(0.46)$. Within three $\mathrm{MoS}_{2} / \mathrm{Ni}_{2} \mathrm{P}$ hybrids, $\mathrm{MoS}_{2} / \mathrm{Ni}_{2} \mathrm{P}-50$ has a minimum Tafel slope ( $58 \mathrm{mV} /$ decade), indicative of the excellent HER performance. It might be a substitute to noble metals in HER application. 


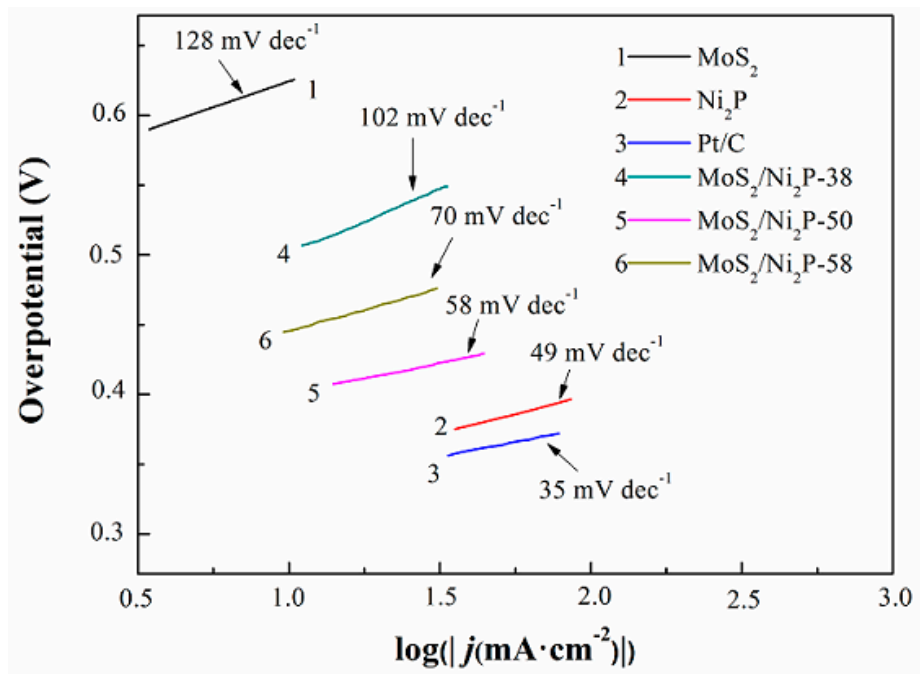

Figure 6. Tafel plots of $\mathrm{MoS}_{2}, \mathrm{Ni}_{2} \mathrm{P}$, three $\mathrm{MoS}_{2} / \mathrm{Ni}_{2} \mathrm{P}$ hybrids, and commercial 20 wt $\% \mathrm{Pt} / \mathrm{C}$. Scan rate: $2 \mathrm{mV} / \mathrm{s}$, potential window: $0.3 \sim 0.65 \mathrm{~V}$.

\subsubsection{Cyclic Voltammetry (CV)}

Cyclic voltammetry (CV) measurement (in a potential window of $-0.6 \sim 0.8 \mathrm{~V}$ ) can be helpful to reveal the reversibility of the electrochemical reaction. $\mathrm{CV}$ curves of $\mathrm{MoS}_{2} / \mathrm{Ni}_{2} \mathrm{P}-38, \mathrm{MoS}_{2} / \mathrm{Ni}_{2} \mathrm{P}-50$ and $\mathrm{MoS}_{2} / \mathrm{Ni}_{2} \mathrm{P}-58$ samples are exhibited in Figure 7; the inset shows those of $\mathrm{MoS}_{2} / \mathrm{Ni}_{2} \mathrm{P}-50$, pure $\mathrm{MoS}_{2}$, pure $\mathrm{Ni}_{2} \mathrm{P}$ and $\mathrm{Pt} / \mathrm{C}$. It can be seen from the determined $\mathrm{CV}$ curves that each of them is composed of an anodic oxidation and a cathodic reduction peak. The quasi-reversible redox peaks may be related to the processes of electrochemical hydrogen adsorption and electrochemical hydrogen desorption [28]. For the three hybrids, cathodic reduction potentials of them are as follows: $-0.21 \mathrm{~V}$ for $\mathrm{MoS}_{2} / \mathrm{Ni}_{2} \mathrm{P}-38$, $-0.11 \mathrm{~V}$ for $\mathrm{MoS}_{2} / \mathrm{Ni}_{2} \mathrm{P}-50$, and $-0.15 \mathrm{~V}$ for $\mathrm{MoS}_{2} / \mathrm{Ni}_{2} \mathrm{P}-58$. In addition, the current density follows the same tendency. Thus, a positive potential and the large current density for $\mathrm{MoS}_{2} / \mathrm{Ni}_{2} \mathrm{P}-50$ composite can be validated, inferring its higher HER property than those of the other two hybrids.

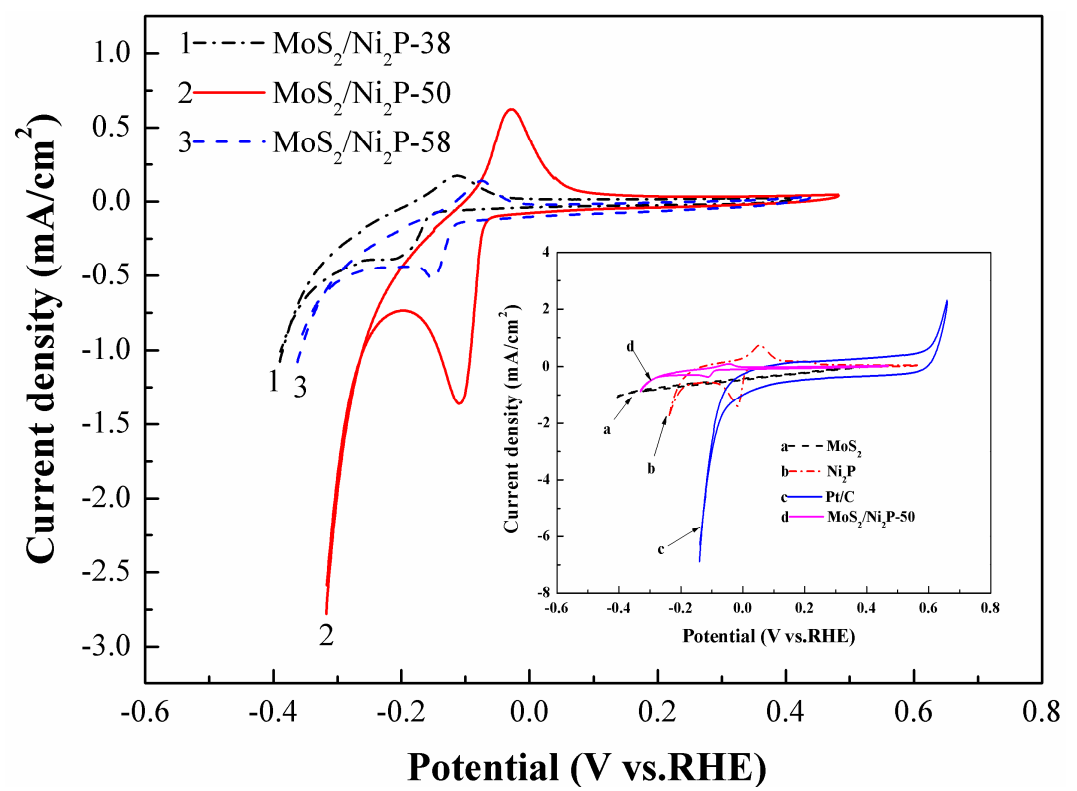

Figure 7. $\mathrm{CV}$ curves of pure $\mathrm{MoS}_{2}, \mathrm{Ni}_{2} \mathrm{P}$, three $\mathrm{MoS}_{2} / \mathrm{Ni}_{2} \mathrm{P}$ hybrids and commercial $20 \mathrm{wt} \% \mathrm{Pt} / \mathrm{C}$. Scan rate: $10 \mathrm{mV} / \mathrm{s}$, potential window: $-0.6 \sim 0.8 \mathrm{~V}$ (vs. RHE). 


\subsubsection{Electrochemical Impedance Spectroscopy (EIS)}

The obtained Nyquist plots for the pure $\mathrm{MoS}_{2}, \mathrm{Ni}_{2} \mathrm{P}$ and three $\mathrm{MoS}_{2} / \mathrm{Ni}_{2} \mathrm{P}$ samples are shown in Figure 8 . The $R_{\mathrm{S}}\left(\mathrm{CPE} R_{\mathrm{ct}}\right)$ equivalent circuit was adopted to analyze the obtained EIS data by use of Zsimpwin software. Where $R_{\mathrm{s}}\left(\Omega \cdot \mathrm{cm}^{2}\right)$ and $R_{\mathrm{ct}}\left(\mathrm{k} \Omega \cdot \mathrm{cm}^{2}\right)$ are the solution resistance and charge transfer resistance. The double layer capacitance $\left(C_{\mathrm{dl}}\right)$ and the exchange current density $\left(j_{0}\right)$ of the electrode are calculated by Equations (6) and (7) [6,66,67]:

$$
\begin{gathered}
C_{\mathrm{dl}}=\left[\frac{Q}{\left(R_{\mathrm{s}}^{-1}+R_{\mathrm{ct}}^{-1}\right)^{1-n}}\right]^{\frac{1}{n}} \\
j_{0}=\frac{R T}{m_{\mathrm{e}} F R_{\mathrm{ct}}}
\end{gathered}
$$

Herein, $Q$ is the capacitance coefficient $\left(\Omega^{-1} \cdot \mathrm{s}^{n} \cdot \mathrm{cm}^{-2}\right)$ of constant phase element (CPE), and $n$ is the phase angle of constant phase element. $R$ is the gas constant $(\mathrm{J} /(\mathrm{K} \cdot \mathrm{mol})), T$ is the absolute temperature $(\mathrm{K}), m_{\mathrm{e}}$ is the number of switched electrons (the parameter of $m_{\mathrm{e}}$ is the same as that in Equation (2)) and $F$ is the Faraday constant. The calculated values of them are also reported in Table 3.

Of all the tested samples, it is no doubt that $\mathrm{Pt} / \mathrm{C}$, with the feature of the largest $C_{\mathrm{dl}}$ and $j_{0}$, exhibits the best HER performance. Apart from the commercial $\mathrm{Pt} / \mathrm{C}$ specimen, among other five lab-made samples, pure $\mathrm{Ni}_{2} \mathrm{P}$ has the largest $C_{\mathrm{dl}}$ and $j_{0}$, followed by the three hybrids and, lastly, by the pure $\mathrm{MoS}_{2}$. From the above results, it seems that $\mathrm{Ni}_{2} \mathrm{P}$ is an ideal HER catalyst, however, the demerit of its instability in alkaline solution will retard its application. Although $C_{\mathrm{dl}}$ and $j_{0}$ of the three hybrids are smaller than $\mathrm{Ni}_{2} \mathrm{P}$, they are much larger than that of $\mathrm{MoS}_{2}$. Among these catalysts, the HER performance of $\mathrm{MoS}_{2} / \mathrm{Ni}_{2} \mathrm{P}-50$ is remarkable.

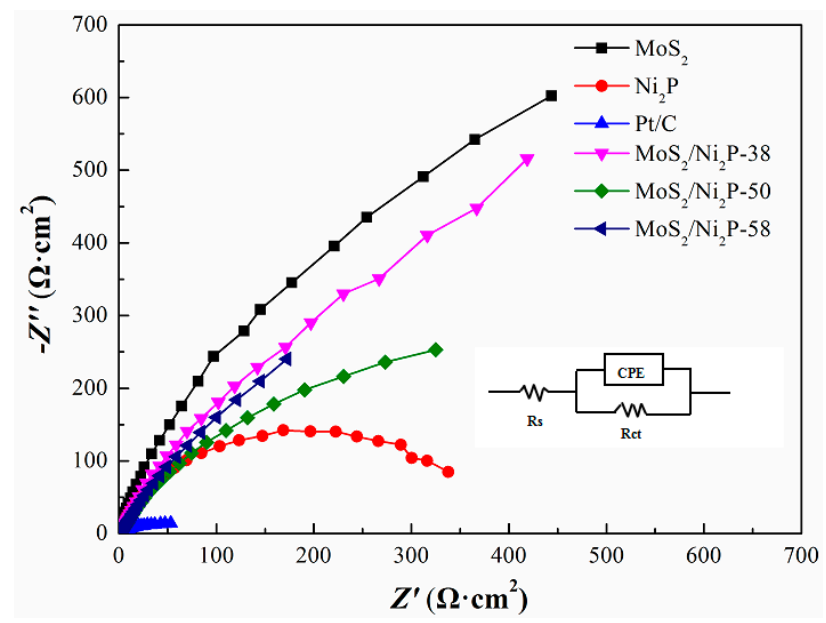

Figure 8. EIS spectra of pure $\mathrm{MoS}_{2}, \mathrm{Ni}_{2} \mathrm{P}$, three $\mathrm{MoS}_{2} / \mathrm{Ni}_{2} \mathrm{P}$ hybrids, and commercial $20 \mathrm{wt} \% \mathrm{Pt} / \mathrm{C}$. Cathodic overpotential: $0.7 \mathrm{~V}$, frequency: $10^{5} \mathrm{~Hz}-0.01 \mathrm{~Hz}$, amplitude of the sinusoidal signal: $5 \mathrm{mV}$.

Table 3. Parameters of solution resistance $\left(R_{\mathrm{S}}\right)$, charge transfer resistance $\left(R_{\mathrm{ct}}\right)$, double-layer capacitance

\begin{tabular}{|c|c|c|c|c|c|}
\hline Samples & $R_{\mathrm{s}} /\left(\Omega \cdot \mathrm{cm}^{2}\right)$ & $R_{\mathrm{ct}} /\left(\mathrm{k} \Omega \cdot \mathrm{cm}^{2}\right)$ & $n$ & $C_{\mathrm{dl}} /\left(\times 10^{-5} \cdot \mathrm{F} / \mathrm{cm}^{2}\right)$ & $j_{0} /\left(\times 10^{-5} \cdot \mathrm{A} / \mathrm{cm}^{2}\right)$ \\
\hline $\mathrm{MoS}_{2}$ & 0.66 & 55.6 & 0.844 & 0.726 & 0.02 \\
\hline $\mathrm{Ni}_{2} \mathrm{P}$ & 0.74 & 0.41 & 0.793 & 7.452 & 3.11 \\
\hline $20 \mathrm{wt} \% \mathrm{Pt} / \mathrm{C}$ & 2.27 & 0.056 & 0.670 & 51.306 & 22.90 \\
\hline $\mathrm{MoS}_{2} / \mathrm{Ni}_{2} \mathrm{P}-38$ & 0.73 & 2.01 & 0.816 & 1.864 & 0.64 \\
\hline $\mathrm{MoS}_{2} / \mathrm{Ni}_{2} \mathrm{P}-50$ & 0.75 & 0.83 & 0.784 & 6.246 & 1.55 \\
\hline $\mathrm{MoS}_{2} / \mathrm{Ni}_{2} \mathrm{P}-58$ & 0.71 & 1.82 & 0.837 & 2.614 & 0.71 \\
\hline
\end{tabular}
$\left(C_{\mathrm{dl}}\right)$, the dimensionless CPE exponent $n$, and exchange current density $\left(j_{0}\right)$ analyzed from the EIS spectra. 


\subsection{DFT Calculations}

The optimized structures of the three catalysts of $\mathrm{MoS}_{2}, \mathrm{Ni}_{2} \mathrm{P}$, and $\mathrm{MoS}_{2} / \mathrm{Ni}_{2} \mathrm{P}$ without hydrogen adsorption, as well as those with one and two adsorbed hydrogen atoms are shown in Figure 9. The adsorption energy $\left(\Delta E_{\text {ads }}\right)$ and Gibbs free energy of adsorption $\left(\Delta G_{\text {ads }}\right)$ for the uptake of hydrogen by the catalyst at $298 \mathrm{~K}$ were calculated using Equations (8) and (9) [30].

$$
\begin{gathered}
\Delta E_{\mathrm{ads}}=E(\text { catalyst }+x \mathrm{H})-E(\text { catalyst }+(x-1) \mathrm{H})-\frac{1}{2} E\left(\mathrm{H}_{2}\right) \\
\Delta G_{a d s}=\Delta E_{\mathrm{ads}}+G_{298}(\text { catalyst }+x \mathrm{H})-G_{298}(\text { catalyst }+(x-1) \mathrm{H})-\frac{1}{2} G_{298}\left(\mathrm{H}_{2}\right)
\end{gathered}
$$

where $E$ (catalyst $+x \mathrm{H}, x=1$ or 2 ) is the COSMO-corrected total energy for the system containing the catalyst support and $x$ adsorbed hydrogen atoms, $E$ (catalyst $+(x-1) \mathrm{H})$ is that of for $(x-1)$ adsorbed hydrogen atoms-including system, and $E\left(\mathrm{H}_{2}\right)$ is the energy of an isolated hydrogen molecule. $G(X)$ is the computed temperature-corrected free energy of the aforesaid species $(X)$ at $298 \mathrm{~K} . \Delta E_{\text {ads }}$ shows the absorption capability catalyst toward the hydrogen atom; the more negative value of $\Delta E_{\text {ads }}$ suggests the stronger interaction between them, and the geometry with the most negative $\Delta E_{\text {ads }}$ will be more stable. The negative value of $\Delta G_{\text {ads }}$ convinces the spontaneous characteristic of the adsorption interaction process.

As for pristine $\mathrm{MoS}_{2}$, there are six edge sites (identified by numbers in Figure 9a) that can absorb the hydrogen atom. After one hydrogen atom capture, $\Delta E_{\mathrm{ads}}\left(\mathrm{MoS}_{2}+\mathrm{H}\right)$ values are as follows: $-16.12 \mathrm{kcal} / \mathrm{mol}$ for site $1,-16.07$ for site $2,-16.08$ for site $3,-12.91$ for site $4,-12.98$ for site 5 , and $-12.97 \mathrm{kcal} / \mathrm{mol}$ for site 6 . Therefore, among these six sites, site 1 is more suitable than others for the anchor of hydrogen atom (Figure $9 \mathrm{~b}$ ). When one hydrogen atom is absorbed, the negative $\Delta G_{\text {ads }}$ of all six hydrogen-containing configurations $(-13.47,-13.34,-13.35,-9.55,-9.67$, and $-9.61 \mathrm{kcal} / \mathrm{mol}$ for hydrogen atom at sites 1-6) indicates the spontaneous characteristic of the hydrogen uptake. After one hydrogen atom adsorption, there are only five edge sites (2-6) for trapping another hydrogen atom. Among geometries for the two hydrogen atoms, the structure with $\Delta E_{\text {ads }}$ of $-14.78 \mathrm{kcal} / \mathrm{mol}$ for $\mathrm{MoS}_{2}$ with sites 1 and 3 for the capture of hydrogen atoms (Figure 9c) is most stable; $\Delta E_{\text {ads }}$ for others are: $-13.52 \mathrm{kcal} / \mathrm{mol}$ for sites 1 and $2,-2.45 \mathrm{kcal} / \mathrm{mol}$ for sites 1 and $4,-12.37 \mathrm{kcal} / \mathrm{mol}$ for sites 1 and 5 , and $-13.19 \mathrm{kcal} / \mathrm{mol}$ for sites 1 and 6 . The values of $\Delta G_{\text {ads }}$ of these five compounds are negative, also inferring the easy uptake of the second hydrogen atom. Of course, by comparison of $\Delta E_{\mathrm{ads}}$, the capture of the first hydrogen atom is easier than that of the second one.

For the case of hydrogen adsorption by $\mathrm{Ni}_{2} \mathrm{P}$, all four sites (labeled by numbers in Figure 9d) are employed to trap hydrogen atoms. Site 3 is desirable for the capture of the first hydrogen atom (Figure 9e), and the value $\Delta E_{\mathrm{ads}}$ for the hydrogen-capturing compound is $-6.095 \mathrm{kcal} / \mathrm{mol}$; those for the other three compounds are $-1.658 \mathrm{kcal} / \mathrm{mol}$ at site $1,-4.889 \mathrm{kcal} / \mathrm{mol}$ at site 2 , and $-4.898 \mathrm{kcal} / \mathrm{mol}$ at site 4 . Values of $\Delta G_{\text {ads }}$ for hydrogen trapper at sites $1-4$ are $-0.235 \mathrm{kcal} / \mathrm{mol}$, $-4.037 \mathrm{kcal} / \mathrm{mol},-4.045 \mathrm{kcal} / \mathrm{mol}$ and $-4.036 \mathrm{kcal} / \mathrm{mol}$, respectively. As for the three systems containing two hydrogens, $\Delta E_{\text {ads }}$ and $\Delta G_{\text {ads }}$ of them are -0.31 and $1.74 \mathrm{kcal} / \mathrm{mol}$ for sites 3 and 1 , 1.78 and $0.33 \mathrm{kcal} / \mathrm{mol}$ for sites 3 and 2 , and -4.19 and $-2.23 \mathrm{kcal} / \mathrm{mol}$ for sites 3 and 4 . Therefore, the $\mathrm{Ni}_{2} \mathrm{P}$ catalyst tends to use sites 3 and 4 to trap hydrogen atoms (Figure $9 \mathrm{f}$ ).

Lastly, for the hydrogen capture by the $\mathrm{MoS}_{2} / \mathrm{Ni}_{2} \mathrm{P}$ hybrid, among the six edge sites of top $\mathrm{MoS}_{2}$ layer (Figure 9g), which is dissimilar to that of the pure $\mathrm{MoS}_{2}$, site 5 is more competent for trapping the first hydrogen atom (Figure $9 \mathrm{~h}$ ), in view of $\Delta E_{\text {ads }}$ and $\Delta G_{\text {ads }}$ as follows: -4.79 and $-3.57 \mathrm{kcal} / \mathrm{mol}$ for site $1,9.15$ and $11.25 \mathrm{kcal} / \mathrm{mol}$ for site $2,-4.89$ and $-4.83 \mathrm{kcal} / \mathrm{mol}$ for site $3,-4.99$ and $-4.64 \mathrm{kcal} / \mathrm{mol}$ for site $4,-6.78$ and $-8.36 \mathrm{kcal} / \mathrm{mol}$ for site 5 , and -5.2 and $-6.87 \mathrm{kcal} / \mathrm{mol}$ for site 6. Additionally, for the adsorption of two hydrogen atoms, sites 5 and 3 (Figure 9i) are the most acceptable, because of the following values of $\Delta E_{\text {ads }}$ and $\Delta G_{\text {ads }}$ for the second hydrogen uptake: -3.81 and $-1.88 \mathrm{kcal} / \mathrm{mol}$ for site $1,-3.56$ and $-1.77 \mathrm{kcal} / \mathrm{mol}$ for site $2,-6.30$ and $-2.73 \mathrm{kcal} / \mathrm{mol}$ for site $3,-6.29$ and $-2.58 \mathrm{kcal} / \mathrm{mol}$ for site $4,7.32$ and $11.90 \mathrm{kcal} / \mathrm{mol}$ for site 6 . Furthermore, it should be 
mentioned that for $\mathrm{S}$ atoms at the sites 4 and 6, the distances between which and the second hydrogen atom are extended, and this hydrogen atom tends to close to the $S$ atoms at sites 3 and 5.

In terms of the DFT calculations results, for the first and second hydrogen uptakes, $\Delta E_{\text {ads }}$ and $\Delta G_{\text {ads }}$ of $\mathrm{MoS}_{2}$ are the most negative, followed by $\mathrm{MoS}_{2} / \mathrm{Ni}_{2} \mathrm{P}$ and $\mathrm{Ni}_{2} \mathrm{P}$. Compared with that of $\mathrm{MoS}_{2}$, affinities of $\mathrm{MoS}_{2} / \mathrm{Ni}_{2} \mathrm{P}$ and $\mathrm{Ni}_{2} \mathrm{P}$ to hydrogen neither too strong nor too weak, indicating its excellent HER performance $[51,68]$. In addition, the $\Delta G_{\text {ads }}$ of $\mathrm{Ni}_{2} \mathrm{P}$ that capturing hydrogen atoms is more close to zero than those of the other two systems, it is sure that the HER property of $\mathrm{Ni}_{2} \mathrm{P}$ is higher than those of $\mathrm{MoS}_{2}$ and $\mathrm{MoS}_{2} / \mathrm{Ni}_{2} \mathrm{P}$ hybrids [51,69]. Thus, it can be concluded that the HER performances for these catalysts are in an order of $\mathrm{Ni}_{2} \mathrm{P}>\mathrm{MoS}_{2} / \mathrm{Ni}_{2} \mathrm{P}>\mathrm{MoS}_{2}$. This deduction is consistent with the experimental tests. Herein, the combination between $\mathrm{MoS}_{2}$ and $\mathrm{Ni}_{2} \mathrm{P}$, and the role of $\mathrm{Ni}_{2} \mathrm{P}$ in the enhancement of $\mathrm{MoS}_{2}$ HER property will be investigated in a further study.

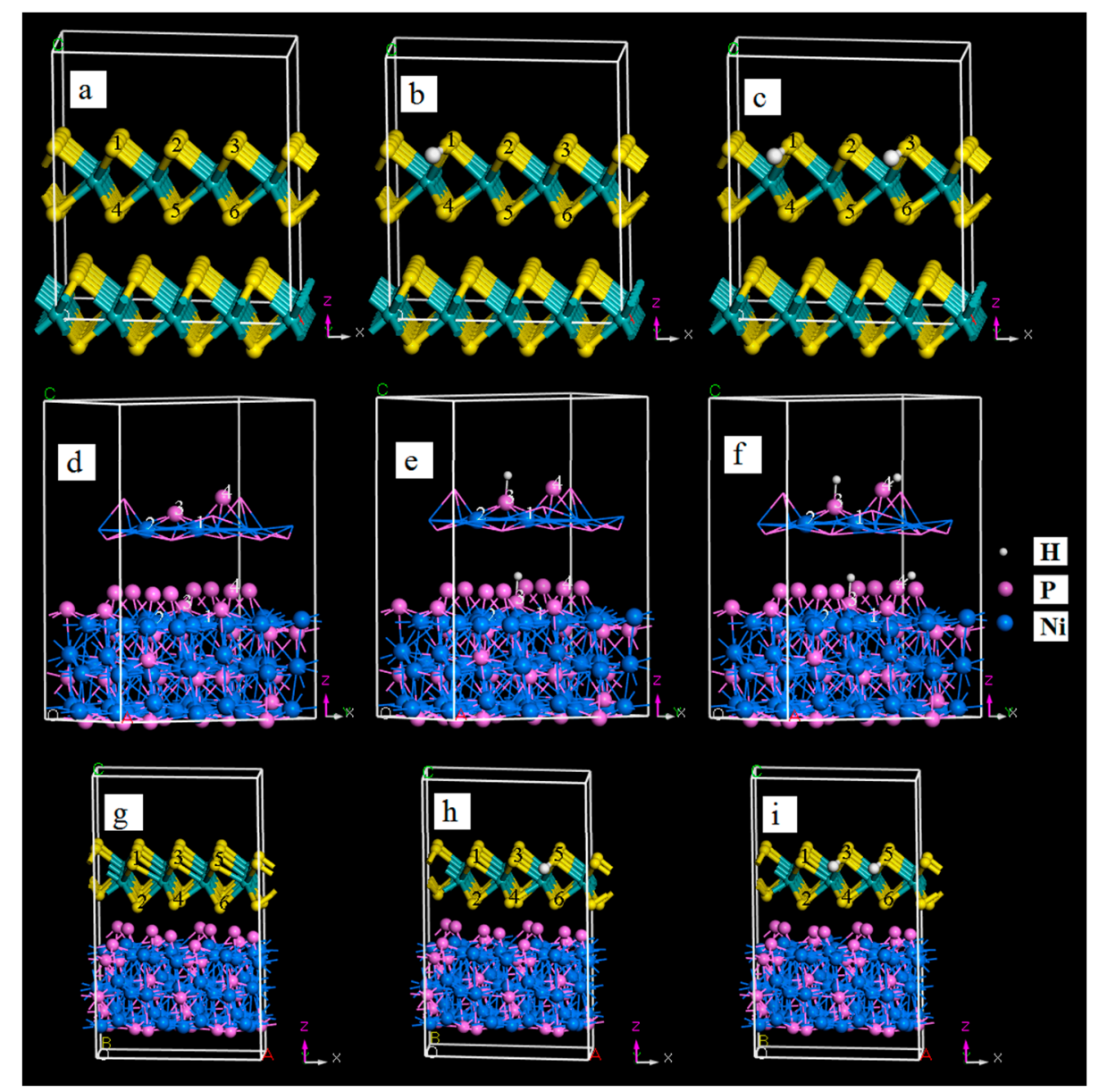

Figure 9. The optimized structures of $\mathrm{MoS}_{2}, \mathrm{Ni}_{2} \mathrm{P}$, and $\mathrm{MoS}_{2} / \mathrm{Ni}_{2} \mathrm{P}$ three catalysts without hydrogen adsorption, as well as those with one and two adsorbed hydrogen atoms. (a) $\mathrm{MoS}_{2}$; (b) $\mathrm{MoS}_{2}-1 \mathrm{H}$; (c) $\mathrm{MoS}_{2}-2 \mathrm{H}$; (d) $\mathrm{Ni}_{2} \mathrm{P}$; (e) $\mathrm{Ni}_{2} \mathrm{P}-1 \mathrm{H}$; (f) $\mathrm{Ni}_{2} \mathrm{P}-2 \mathrm{H}$; (g) $\mathrm{MoS}_{2} / \mathrm{Ni}_{2} \mathrm{P}$; (h) $\mathrm{MoS}_{2} / \mathrm{Ni}_{2} \mathrm{P}-1 \mathrm{H}$; and (i) $\mathrm{MoS}_{2} / \mathrm{Ni}_{2} \mathrm{P}-2 \mathrm{H}$.

\subsection{HER Stability of the $\mathrm{MoS}_{2} / \mathrm{Ni}_{2} \mathrm{P}$ Hybrids}

For practical applications, in addition to the HER activity mentioned above, the stability of electrocatalysts is another important criterion to evaluate the catalytic activity. To assess the durability of pure $\mathrm{MoS}_{2}, \mathrm{Ni}_{2} \mathrm{P}$, and the $\mathrm{MoS}_{2} / \mathrm{Ni}_{2} \mathrm{P}-50$ hybrid, continuous CV tests for 1000 cycles with the potential in range of -1.0 to $0.4 \mathrm{~V}$ were conducted at a scan rate of $50 \mathrm{mV} / \mathrm{s}$ in $1.0 \mathrm{~mol} / \mathrm{L} \mathrm{KOH}$ (Figure 10). By comparison of polarization curves of these three samples before and after 1000 cycles, the cathodic current densities of them decrease somewhat after tests. Compared with electrocatalytic 
behaviors of pure $\mathrm{MoS}_{2}$ and $\mathrm{Ni}_{2} \mathrm{P}$, the $\mathrm{MoS}_{2} / \mathrm{Ni}_{2} \mathrm{P}-50$ hybrid just shows a slight decay, and thereby exhibits an excellent durability in the HER process.

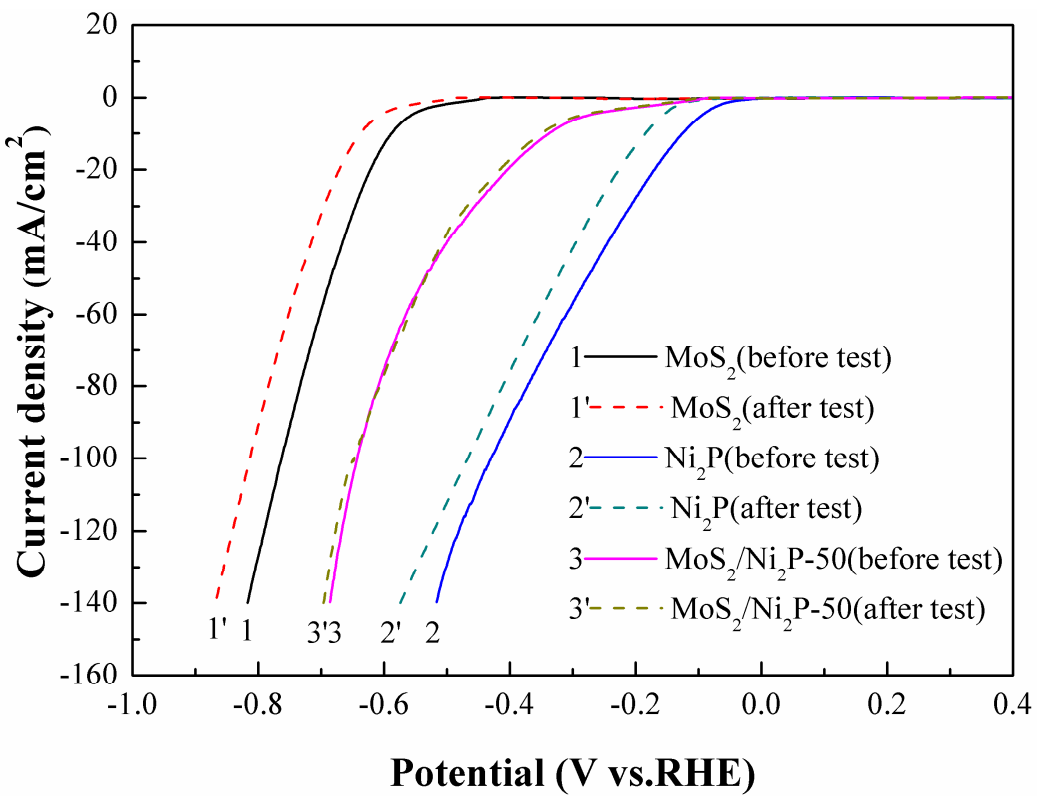

Figure 10. Stability tests for the pure $\mathrm{MoS}_{2}, \mathrm{Ni}_{2} \mathrm{P}$, and $\mathrm{MoS}_{2} / \mathrm{Ni}_{2} \mathrm{P}-50$ hybrid. Scan rate: $50 \mathrm{mV} / \mathrm{s}$, potential window: -1.0 to $0.4 \mathrm{~V}$ (vs. RHE).

\section{Conclusions}

In this work, morphologies, crystallinities, and chemical components of pure $\mathrm{MoS}_{2}, \mathrm{Ni}_{2} \mathrm{P}$, and three $\mathrm{MoS}_{2} / \mathrm{Ni}_{2} \mathrm{P}$ hybrids obtained via a hydrothermal synthesis process were characterized. Then, HER performances of them in $1.0 \mathrm{~mol} / \mathrm{L} \mathrm{KOH}$ solution were evaluated. The main conclusions are summarized as follows:

(1) The result of DFT calculation is in consistence with that of experimental test. The incorporated $\mathrm{Ni}_{2} \mathrm{P}$ observably enhances the HER property of $\mathrm{MoS}_{2}$. Among the three fabricated kinds of catalysts, the HER performance of them follows the trend: $\mathrm{Ni}_{2} \mathrm{P}>\mathrm{MoS}_{2} / \mathrm{Ni}_{2} \mathrm{P}>\mathrm{MoS}_{2}$.

(2) The $\mathrm{MoS}_{2} / \mathrm{Ni}_{2} \mathrm{P}-50$ shows a large cathodic current density $\left(70 \mathrm{~mA} / \mathrm{cm}^{2}\right.$ at $\left.-0.48 \mathrm{~V}\right)$ and small Tafel slope $(\sim 58 \mathrm{mV} /$ decade), thus exhibiting the higher HER activity than other two $\mathrm{MoS}_{2} / \mathrm{Ni}_{2} \mathrm{P}$ hybrids.

(3) The excellent HER performance of $\mathrm{MoS}_{2} / \mathrm{Ni}_{2} \mathrm{P}-50$ hybrid can be due to the desirable conductivity, the uniform morphology, large specific surface area, and favorable stability.

Author Contributions: F.Y. and N.K. prepared the manuscript. L.S. designed this work and gave the guidance for HER evaluation. F.Y., J.Y., N.K., and S.H. performed the experiments and the measurement of HER. J.H., X.W., and F.Y. analyzed the data and reviewed the manuscript. All authors read and approved the manuscript.

Funding: This research was funded by the Hebei Provincial Natural Science Foundation of China (grant number B2016203012), and the Science and Technology Support Key Research and Development Program of Qinhuangdao, China (grant number 201703A012).

Acknowledgments: We are sincerely thankful to the editors and the reviewers for giving valuable and instructive comments for the revision of this manuscript.

Conflicts of Interest: The authors declare no conflict of interest. 


\section{References}

1. Han, L.; Yu, T.W.; Lei, W.; Liu, W.W.; Feng, K.; Ding, Y.L.; Jiang, G.P.; Xu, P.; Chen, Z.W. Nitrogen-doped carbon nanocones encapsulating with nickel-cobalt mixed phosphides for enhanced hydrogen evolution reaction. J. Mater. Chem. A 2017, 5, 16568-16572. [CrossRef]

2. Li, Y.; Cai, P.W.; Ci, S.Q.; Wen, Z.H. Strongly coupled 3D nanohybrids with $\mathrm{Ni}_{2} \mathrm{P} /$ carbon nanosheets as $\mathrm{pH}$-universal hydrogen evolution reaction electrocatalysts. ChemElectroChem 2017, 4, 340-344. [CrossRef]

3. Li, J.Y.; Li, J.; Zhou, X.M.; Xia, Z.M.; Gao, W.; Qu, Y.Q. Highly efficient and robust nickel phosphides as bifunctional electrocatalysts for overall water-splitting. ACS Appl. Mater. Interfaces 2016, 8, 10826-10834. [CrossRef] [PubMed]

4. Song, L.Z.; Wang, X.L.; Wen, F.S.; Niu, L.J.; Shi, X.M.; Yan, J.Y. Hydrogen evolution reaction performance of the molybdenum disulfide/nickel-phosphorus composites in alkaline solution. Int. J. Hydrog. Energy 2016, 41, 18942-18952. [CrossRef]

5. Wang, D.Z.; Pan, Z.; Wu, Z.Z.; Wang, Z.P.; Liu, Z.H. Hydrothermal synthesis of $\mathrm{MoS}_{2}$ nanoflowers as highly efficient hydrogen evolution reaction catalysts. J. Power Sources 2014, 264, 229-234. [CrossRef]

6. Wang, L.X.; Li, Y.; Yin, X.C.; Wang, Y.Z.; Lu, L.; Song, A.L.; Xia, M.R.; Li, Z.P.; Qin, X.J.; Shao, G.J. Comparison of three nickel-based carbon composite catalysts for hydrogen evolution reaction in alkaline solution. Int. J. Hydrog. Energy 2017, 42, 22655-22662. [CrossRef]

7. Cai, Z.X.; Song, X.H.; Wang, Y.R.; Chen, X. Electrodeposition-assisted synthesis of $\mathrm{Ni}_{2} \mathrm{P}$ nanosheets on 3D graphene/ $\mathrm{Ni}$ foam electrode and its performance for electrocatalytic hydrogen production. ChemElectroChem 2015, 2, 1665-1671. [CrossRef]

8. Morales-Guio, C.G.; Stern, L.A.; Hu, X. Nanostructured hydrotreating catalysts for electrochemical hydrogen evolution. Chem. Soc. Rev. 2014, 43, 6555-6569. [CrossRef] [PubMed]

9. Merki, D.; Hu, X. Recent developments of molybdenum and tungsten sulfides as hydrogen evolution catalysts. Energy Environ. Sci. 2011, 4, 3878-3888. [CrossRef]

10. Khan, M.; Yousaf, A.B.; Chen, M.M.; Wei, C.S.; Wu, X.; Huang, N.D.; Qi, Z.M.; Li, L.B. Molybdenum sulfide/graphene-carbon nanotube nanocomposite material for electrocatalytic applications in hydrogen evolution reactions. Nano Res. 2016, 9, 837-848. [CrossRef]

11. Jing, S.Y.; Zhang, L.S.; Luo, L.; Lu, J.J.; Yin, S.B.; Shen, P.K.; Tsiakaras, P. N-doped porous molybdenum carbide nanobelts as efficient catalysts for hydrogen evolution reaction. Appl. Catal. B Environ. 2018, 224, 533-540. [CrossRef]

12. Yin, X.C.; Sun, G.; Song, A.L.; Wang, L.X.; Wang, Y.Z.; Dong, H.F.; Shao, G.J. A novel structure of $\mathrm{Ni}-\left(\mathrm{MoS}_{2} / \mathrm{GO}\right)$ composite coatings deposited on Ni foam under supergravity field as efficient hydrogen evolution reaction catalysts in alkaline solution. Electrochim. Acta 2017, 249, 52-63. [CrossRef]

13. Yin, X.C.; Sun, G.; Wang, L.X.; Bai, L.; Su, L.; Wang, Y.Z.; Du, Q.H.; Shao, G.J. 3D hierarchical network $\mathrm{NiCo}_{2} \mathrm{~S}_{4}$ nanoflakes grown on $\mathrm{Ni}$ foam as efficient bifunctional electrocatalysts for both hydrogen and oxygen evolution reaction in alkaline solution. Int. J. Hydrog. Energy 2017, 42, 25267-25276. [CrossRef]

14. Popczun, E.J.; McKone, J.R.; Read, C.G.; Biacchi, A.J.; Wiltrout, A.M.; Lewis, N.S.; Schaak, R.E. Nanostructured nickel phosphide as an electrocatalyst for the hydrogen evolution reaction. J. Am. Chem. Soc. 2013, 135, 9267-9270. [CrossRef] [PubMed]

15. Feng, L.G.; Vrubel, H.; Bensimon, M.; Hu, X. Easily-prepared dinickel phosphide $\left(\mathrm{Ni}_{2} \mathrm{P}\right)$ nanoparticles as an efficient and robust electrocatalyst for hydrogen evolution. Phys. Chem. Chem. Phys. 2014, 16, 5917-5921. [CrossRef] [PubMed]

16. Liu, Y.R.; Hu, W.H.; Li, X.; Dong, B.; Shang, X.; Han, G.Q.; Chai, Y.M.; Liu, Y.Q.; Liu, C.G. One-pot synthesis of hierarchical $\mathrm{Ni}_{2} \mathrm{P} / \mathrm{MoS}_{2}$ hybrid electrocatalysts with enhanced activity for hydrogen evolution reaction. Appl. Surf. Sci. 2016, 383, 276-282. [CrossRef]

17. Pan, Y.; Yang, N.; Chen, Y.J.; Lin, Y.; Li, Y.P.; Liu, Y.Q.; Liu, C.G. Nickel phosphide nanoparticles-nitrogen-doped graphene hybrid as an efficient catalyst for enhanced hydrogen evolution activity. J. Power Sources 2015, 297, 45-52. [CrossRef]

18. Lu, G.J.; Evans, P.; Zangari, G. Electrocatalytic properties of Ni-based alloys toward hydrogen evolution reaction in acid media. J. Electrochem. Soc. 2003, 150, A551-A557. [CrossRef] 
19. Peng, S.G.; Li, L.L.; Han, X.P.; Sun, W.P.; Srinivasan, M.; Mhaisalkar, S.G.; Cheng, F.Y.; Yan, Q.Y.; Chen, J.; Ramakrishna, S. Cobalt sulfide nanosheet/graphene/carbon nanotube nanocomposites as flexible electrodes for hydrogen evolution. Angew. Chem. 2014, 53, 12594-12599.

20. Zhang, H.X.; Yang, B.; Wu, X.L.; Li, Z.J.; Lei, L.C.; Zhang, X.W. Polymorphic $\mathrm{CoSe}_{2}$ with mixed orthorhombic and cubic phases for highly efficient hydrogen evolution reaction. ACS Appl. Mater. Interfaces 2015, 7, 1772-1779. [CrossRef] [PubMed]

21. Li, Y.H.; Liu, P.F.; Pan, L.F.; Wang, H.F.; Yang, Z.Z.; Zheng, L.R.; Hu, P.; Zhao, H.J.; Gu, L.; Yang, H.G. Local atomic structure modulations activate metal oxide as electrocatalyst for hydrogen evolution in acidic water. Nat. Commun. 2015, 6, 8064. [CrossRef] [PubMed]

22. Chen, W.F.; Wang, C.H.; Sasaki, K.; Marinkovic, N.; Xu, W.; Muckerman, J.T.; Zhu, Y.; Adzic, R.R. Highly active and durable nanostructured molybdenum carbide electrocatalysts for hydrogen production. Energy Environ. Sci. 2013, 6, 943-951. [CrossRef]

23. Chen, W.F.; Sasaki, K.; Ma, C.; Frenkel, A.I.; Marinkovic, N.; Muckerman, J.T.; Zhu, Y.M.; Adzic, R.R. Hydrogen-evolution catalysts based on non-noble metal nickel-molybdenum nitride nanosheets. Angew. Chem. Int. Ed. 2012, 51, 6131-6135. [CrossRef] [PubMed]

24. Du, H.F.; Gu, S.; Liu, R.W.; Li, C.M. Highly active and inexpensive iron phosphide nanorods electrocatalyst towards hydrogen evolution reaction. Int. J. Hydrog. Energy 2015, 40, 14272-14278. [CrossRef]

25. Kibsgaard, J.; Chen, Z.B.; Reinecke, B.N.; Jaramillo, T.F. Engineering the surface structure of $\mathrm{MoS}_{2}$ to preferentially expose active edge sites for electrocatalysis. Nat. Mater. 2012, 11, 963-969. [CrossRef] [PubMed]

26. Merki, D.; Fierro, S.; Vrubel, H.; Hu, X.L. Amorphous molybdenum sulfide films as catalysts for electrochemical hydrogen production in water. Chem. Sci. 2011, 2, 1262-1267. [CrossRef]

27. Liu, Y.R.; Hu, W.H.; Li, X.; Dong, B.; Shang, X.; Han, G.Q.; Chai, Y.M.; Liu, Y.Q.; Liu, C.G. Facile one-pot synthesis of $\mathrm{CoS}_{2}-\mathrm{MoS}_{2} / \mathrm{CNTs}$ as efficient electrocatalyst for hydrogen evolution reaction. Appl. Surf. Sci. 2016, 384, 51-57. [CrossRef]

28. He, J.; Song, L.Z.; Yan, J.Y.; Kang, N.; Zhang, Y.L.; Wang, W. Hydrogen evolution reaction property in alkaline solution of molybdenum disulfide modified by surface anchor of Nickel—Phosphorus coating. Metals 2017, 7, 211.

29. Bian, X.J.; Zhu, J.; Liao, L.; Scanlon, M.D.; Ge, P.Y.; Ji, C.; Girault, H.H.; Liu, B.H. Nanocomposite of MoS $_{2}$ on ordered mesoporous carbon Nanospheres: A highly active catalyst for electrochemical hydrogen evolution. Electrochem. Commun. 2012, 22, 128-132. [CrossRef]

30. Tsai, C.; Abild-Pedersen, F.; Nørskov, J.K. Tuning the $\mathrm{MoS}_{2}$ edge-site activity for hydrogen evolution via support interactions. Nano Lett. 2014, 14, 1381-1387. [CrossRef] [PubMed]

31. Jing, Y.; Ortiz-Quiles, E.O.; Cabrera, C.R.; Chen, Z.F.; Zhou, Z. Layer-by-layer hybrids of $\mathrm{MoS}_{2}$ and reduced graphene oxide for lithium ion batteries. Electrochim. Acta 2014, 147, 392-400. [CrossRef]

32. Yu, Y.F.; Huang, S.Y.; Li, Y.P.; Steinmann, S.N.; Yang, W.T.; Cao, L.Y. Layer-dependent electrocatalysis of $\mathrm{MoS}_{2}$ for hydrogen evolution. Nano Lett. 2014, 14, 553-558. [CrossRef] [PubMed]

33. Liang, T.; Sawyer, W.G.; Perry, S.S.; Sinnott, S.B.; Phillpot, S.R. Energetics of oxidation in $\mathrm{MoS}_{2}$ nanoparticles by density functional theory. J. Phys. Chem. C 2011, 115, 10606-10616. [CrossRef]

34. Wu, Z.Z.; Fang, B.Z.; Wang, Z.P.; Wang, C.L.; Liu, Z.H.; Liu, F.Y.; Wang, W.; Alfantazi, A.; Wang, D.Z.; Wilkinson, D.P. $\mathrm{MoS}_{2}$ nanosheets: A designed structure with high active site density for the hydrogen evolution reaction. ACS Catal. 2013, 3, 2101-2107. [CrossRef]

35. Wang, H.T.; Lu, Z.Y.; Kong, D.S.; Sun, J.; Hymel, T.M.; Cui, Y. Electrochemical tuning of $\mathrm{MoS}_{2}$ nanoparticles on three-dimensional substrate for efficient hydrogen evolution. ACS Nano 2014, 8, 4940-4947. [CrossRef] [PubMed]

36. Deng, J.; Li, H.B.; Xiao, J.P.; Tu, Y.C.; Deng, D.H.; Yang, H.X.; Tian, H.F.; Li, J.Q.; Ren, P.J.; Bao, X.H. Triggering the electrocatalytic hydrogen evolution activity of inert two-dimensional $\mathrm{MoS}_{2}$ surface via single-atom metal doping. Energy Environ. Sci. 2015, 8, 1594-1601. [CrossRef]

37. Huang, X.; Zeng, Z.Y.; Bao, S.Y.; Wang, M.F.; Qi, X.Y.; Fan, Z.X.; Zhang, H. Solution-phase epitaxial growth of noble metal nanostructures on dispersible single-layer molybdenum disulfide nanosheets. Nat. Commun. 2013, 4, 1444-1452. [CrossRef] [PubMed] 
38. Hu, W.H.; Han, G.Q.; Liu, Y.R.; Dong, B.; Chai, Y.M.; Liu, Y.Q.; Liu, C.G. Ultrathin $\mathrm{MoS}_{2}$-coated carbon nanospheres as highly efficient electrocatalyts for hydrogen evolution reaction. Int. J. Hydrog. Energy 2015, 40, 6552-6558. [CrossRef]

39. Chen, Z.B.; Cummins, D.; Reinecke, B.N.; Clark, E.; Sunkara, M.K.; Jaramillo, T.F. Core-shell $\mathrm{MoO}_{3}-\mathrm{MoS}_{2}$ nanowires for hydrogen evolution: A functional design for electrocatalytic materials. Nano Lett. 2011, 11, 4168-4175. [CrossRef] [PubMed]

40. Sun, X.; Huo, J.; Yang, Y.D.; Xu, L.; Wang, S.Y. The $\mathrm{Co}_{3} \mathrm{O}_{4}$ nanosheet array as support for MoS 2 as highly efficient electrocatalysts for hydrogen evolution reaction. J. Energy Chem. 2017, 26, 1136-1139. [CrossRef]

41. Li, Y.G.; Wang, H.L.; Xie, L.M.; Liang, Y.Y.; Hong, G.S.; Dai, H.J. MoS 2 nanoparticles grown on Graphene: An advanced catalyst for the hydrogen evolution reaction. J. Am. Chem. Soc. 2011, 133, 7296-7299. [CrossRef] [PubMed]

42. Li, X.D.; Yu, S.; Wu, S.Q.; Wen, Y.H.; Zhou, S.; Zhu, Z.Z. Structural and electronic properties of superlattice composed of graphene and monolayer $\mathrm{MoS}_{2}$. J. Phys. Chem. C 2013, 117, 15347-15353. [CrossRef]

43. Zhang, J.M.; Zhao, L.; Liu, A.P.; Li, X.Y.; Wu, H.P.; Lu, C.D. Three-dimensional $\mathrm{MoS}_{2} / \mathrm{rGO}$ hydrogel with extremely high double-layer capacitance as active catalyst for hydrogen evolution reaction. Electrochim. Acta 2015, 182, 652-658. [CrossRef]

44. Paseka, I. Hydrogen evolution reaction on Ni-P alloys: The internal stress and the activities of electrodes. Electrochim. Acta 2008, 53, 4537-4543. [CrossRef]

45. Liu, Q.; Gu, S.; Li, C.M. Electrodeposition of Nickel-Phosphorus nanoparticles film as a Janus electrocatalyst for electro-splitting of water. J. Power Sources 2015, 299, 342-346. [CrossRef]

46. Balaraju, J.N.; Jahan, S.M.; Jain, A.; Rajama, K.S. Structure and phase transformation behavior of electroless Ni-P alloys containing tin and tungsten. J. Alloys Compd. 2007, 436, 319-327. [CrossRef]

47. Pu, Z.H.; Liu, Q.; Tang, C.; Asiri, A.M.; Sun, X.P. $\mathrm{Ni}_{2} \mathrm{P}$ nanoparticle films supported on a Ti plate as an efficient hydrogen evolution cathode. Nanoscale 2014, 6, 11031-11034. [CrossRef] [PubMed]

48. Raybaud, P.; Hafner, J.; Kresse, G.; Kasztelan, S.; Toulhoat, H. Ab initio study of the $\mathrm{H}_{2}-\mathrm{H}_{2} \mathrm{~S} / \mathrm{MoS}_{2}$ gas-solid Interface: The nature of the catalytically active sites. J. Catal. 2000, 189, 129-146. [CrossRef]

49. Ouyang, F.P.; Yang, Z.X.; Ni, X.; Wu, N.N.; Chen, Y.; Xiong, X. Hydrogenation-induced edge magnetization in armchair $\mathrm{MoS}_{2}$ nanoribbon and electric field effects. Appl. Phys. Lett. 2014, 104, 071901. [CrossRef]

50. Moon, J.S.; Jang, J.H.; Kim, E.G.; Chung, Y.H.; Yoo, S.J.; Lee, Y.K. The nature of active sites of $\mathrm{Ni}_{2} \mathrm{P}$ electrocatalyst for hydrogen evolution reaction. J. Catal. 2015, 326, 92-99. [CrossRef]

51. Liu, P.; Rodriguez, J.A. Catalysts for hydrogen evolution from the $[\mathrm{NiFe}]$ hydrogenase to the $\mathrm{Ni}_{2} \mathrm{P}(001)$ surface: The importance of ensemble effect. J. Am. Chem. Soc. 2005, 127, 14871-14878. [CrossRef] [PubMed]

52. Wang, X.L.; Song, L.Z.; Yang, F.F.; He, J. Investigation of phosphate adsorption by a polyethersulfone-type affinity membrane using experimental and DFT methods. Desalin. Water Treat. 2016, 57, 25036-25056. [CrossRef]

53. Li, H.; Ma, L.; Chen, W.X.; Wang, J.M. Synthesis of $\mathrm{MoS}_{2} / \mathrm{C}$ nanocomposites by hydrothermal route used as Li-ion intercalation electrode materials. Mater. Lett. 2009, 63, 1363-1365. [CrossRef]

54. Li, D.; Senevirathne, K.; Aquilina, L.; Brock, S.L. Effect of synthetic levers on nickel phosphide nanoparticle formation: $\mathrm{Ni}_{5} \mathrm{P}_{4}$ and $\mathrm{NiP}_{2}$. Inorg. Chem. 2015, 54, 7968-7975. [CrossRef] [PubMed]

55. Liu, Z.Y.; Huang, X.; Zhu, Z.B.; Dai, J.H. A simple mild hydrothermal route for the synthesis of nickel phosphide powders. Ceram. Int. 2010, 36, 1155-1158. [CrossRef]

56. Wang, H.W.; Skeldon, P.; Thompson, G.E. XPS studies of $\mathrm{MoS}_{2}$ formation from ammonium tetrathiomolybdate solutions. Surf. Coat. Technol. 1997, 91, 200-207. [CrossRef]

57. Meng, C.H.; Liu, Z.Y.; Zhang, T.R.; Zhai, J. Layered $\mathrm{MoS}_{2}$ nanoparticles on $\mathrm{TiO}_{2}$ nanotubes by photocatalytic strategy as high-performance electrocatalysts for hydrogen evolution reaction. Green Chem. 2015, 17, 2764-2768. [CrossRef]

58. Koroteev, V.O.; Bulusheva, L.G.; Asanov, I.P.; Shlyakhova, E.V.; Vyalikh, D.V.; Okotrub, A.V. Charge transfer in the $\mathrm{MoS}_{2}$ /carbon nanotube composite. J. Phys. Chem. C 2011, 115, 21199-21204. [CrossRef]

59. Huang, Z.P.; Chen, Z.B.; Chen, Z.Z.; Lv, C.C.; Meng, H.; Zhang, C. $\mathrm{Ni}_{12} \mathrm{P}_{5}$ nanoparticles as an efficient catalyst for hydrogen generation via electrolysis and photoelectrolysis. ACS Nano 2014, 8, 8121-8129. [CrossRef] [PubMed] 
60. Pan, Y.; Hu, W.H.; Liu, D.P.; Liu, Y.Q.; Liu, C.G. Carbon nanotubes decorated with nickel phosphide nanoparticles as efficient nanohybrid electrocatalysts for the hydrogen evolution reaction. J. Mater. Chem. A 2015, 3, 13087-13094. [CrossRef]

61. Kim, S.M.; Jin, S.H.; Lee, Y.J.; Lee, M.H. Design of nickel electrodes by Electrodeposition: Effect of internal stress on hydrogen evolution reaction in alkaline solutions. Electrochim. Acta 2017, 252, 67-75. [CrossRef]

62. Zeng, M.; Li, Y.G. Recent advances in heterogeneous electrocatalysts for the hydrogen evolution reaction. J. Mater. Chem. A 2015, 3, 14942-14962. [CrossRef]

63. Rosalbino, F.; Delsante, S.; Borzone, G.; Angelini, E. Electrocatalytic behaviour of Co-Ni-R (R = Rare earth metal) crystalline alloys as electrode materials for hydrogen evolution reaction in alkaline medium. Int. J. Hydrog. Energy 2008, 33, 6696-6703. [CrossRef]

64. Zheng, H.T.; Mathe, M. Hydrogen evolution reaction on single crystal $\mathrm{WO}_{3} / \mathrm{C}$ nanoparticles supported on carbon in acid and alkaline solution. Int. J. Hydrog. Energy 2011, 36, 1960-1964. [CrossRef]

65. Kong, D.S.; Cha, J.J.; Wang, H.T.; Lee, H.R.; Cui, Y. First-row transition metal dichalcogenide catalysts for hydrogen evolution reaction. Energy Environ. Sci. 2013, 6, 3553-3558. [CrossRef]

66. Brug, G.J.; Van Den Eeden, A.L.G.; Sluyters-Rehbach, M.; Sluyters, J.H. The analysis of electrode impedances complicated by the presence of a constant phase element. J. Electroanal. Chem. Interfacial Electrochem. 1984, 176, 275-295. [CrossRef]

67. Kunhiraman, A.K.; Ramasamy, M.; Ramanathan, S. Efficient hydrogen evolution catalysis triggered by electrochemically anchored platinum nano-islands on functionalized-MWCNT. Int. J. Hydrog. Energy 2017, 42, 9881-9891. [CrossRef]

68. Wei, Z.D.; Yan, A.Z.; Feng, Y.C.; Li, L.; Sun, C.X.; Shao, Z.G.; Shen, P.K. Study of hydrogen evolution reaction on Ni-P amorphous alloy in the light of experimental and quantum chemistry. Electrochem. Commun. 2007, 9, 2709-2715. [CrossRef]

69. Hinnemann, B.; Moses, P.G.; Bonde, J.; Jørgensen, K.P.; Nielsen, J.H.; Horch, S.; Chorkendorff, I.; Nørskov, J.K. Biomimetic hydrogen evolution: $\mathrm{MoS}_{2}$ nanoparticles as catalyst for hydrogen evolution. J. Am. Chem. Soc. 2005, 127, 5308-5309. [CrossRef] [PubMed] 